\author{
UNIVERSIDADE DE SÃO PAULO - USP \\ FACULDADE DE ODONTOLOGIA \\ DEPARTAMENTO DE ODONTOLOGIA SOCIAL \\ PROGRAMA DE PÓS-GRADUAÇÃO EM CIÊNCIAS \\ ODONTOLÓGICAS
}

MÁRCIA DELBON JORGE

\title{
A ASSISTÊNCIA DOMICILIÁRIA ODONTOLÓGICA SOB A PERSPECTIVA DA BIOÉTICA PERSONALISTA
}




\section{Marcia Delbon Jorge}

\section{A Assistência Domiciliária Odontológica sob a perspectiva da \\ Bioética Personalista}

Dissertação apresentada à Faculdade de Odontologia da Universidade de São Paulo, para obtenção do título de Mestre pelo Programa de PósGraduação em Ciências Odontológicas.

Área de Concentração: Odontologia Social

Orientador: Prof. Dr. Dalton Luiz de Paula Ramos 


\section{FOLHA DE APROVAÇÃO}

Jorge MD. A assistência domiciliária odontológica sob a perspectiva da bioética personalista [Dissertação de Mestrado]. São Paulo: Faculdade de Odontologia da USP; 2006.

São Paulo,

\section{BANCA EXAMINADORA}

1) $\operatorname{Prof}(\mathrm{a}) . \operatorname{Dr}(\mathrm{a})$.

Titulação:

Julgamento:

Assinatura

2) $\operatorname{Prof}(\mathrm{a}) . \operatorname{Dr}(\mathrm{a})$.

Titulação:

Julgamento:

Assinatura

3) Prof (a). Dr (a).

Titulação:

Julgamento:

Assinatura 


\section{DEDICATÓRIA}




\section{DEDICATÓRIA}

A minha mãe Tercília

Ao meu pai Alcebíades (in memoriam)

Pelo amor incondicional.

A minha irmã Maria do Carmo

Ao meu irmão Henrique César (in memorian)

Com carinho e saudade.

A minha família

Waldyr, que me ampara na alegria e na tristeza e que muito fez para que este trabalho chegasse a termo, com amor eterno.

Eliza, Angellica, Georgia e Anthonio, pelo amor, compreensão e apoio em todas as horas e pelo sentido que deram a minha vida, com amor incondicional.

E àqueles que fazem parte da minha família de coração! - pelo incentivo no meu percurso mostrando-me que sempre vale a pena. 
AGRADECIMENTOS 


\section{AGRADECIMENTOS}

Ao Prof. Dr. Dalton Luiz de Paula Ramos, por acreditar no meu trabalho e, principalmente, por fornecer as ferramentas necessárias para que eu me tornasse uma profissional mais humana. Nunca é tarde para aprender.

À Profa. Dra. Vânia Martins B. O. Funaro, pela presteza e pontualidade nas revisões bibliográficas e pelo carinho com que se relaciona.

Às secretárias do departamento, Sonia, Laura e Eliana pelo sorriso amigo em todas as situações.

Ao Programa de Pós-Graduação em Ciências Odontológicas, PPGCO, pela oportunidade de realização de trabalhos em minha área de pesquisa e atuação profissional.

Aos amigos, próximos e distantes, do PPGCO, pelo auxílio nas tarefas desenvolvidas durante o curso e apoio na revisão deste trabalho.

À equipe do Programa de Atendimento Domiciliário do Hospital Universitário da Universidade de São Paulo (PAD-HU/USP), sem o qual esse trabalho perderia o sentido.

A todos com quem me relacionei ao longo do curso: obrigada por me ensinarem a beleza que há na diversidade de pensamentos. 
BOAS PALAVRAS

"Tudo no mundo começou com um sim. Uma molécula disse sim a outra molécula e nasceu a vida (...) Deus é o mundo. A verdade é sempre um contato interior inexplicável. A minha vida, a mais verdadeira, é irreconhecível, extremamente interior e não tem uma só palavra que a signifique." (Clarice Lispector in A Hora da Estrela. Rio de Janeiro: Rocco, 1998. P.11).

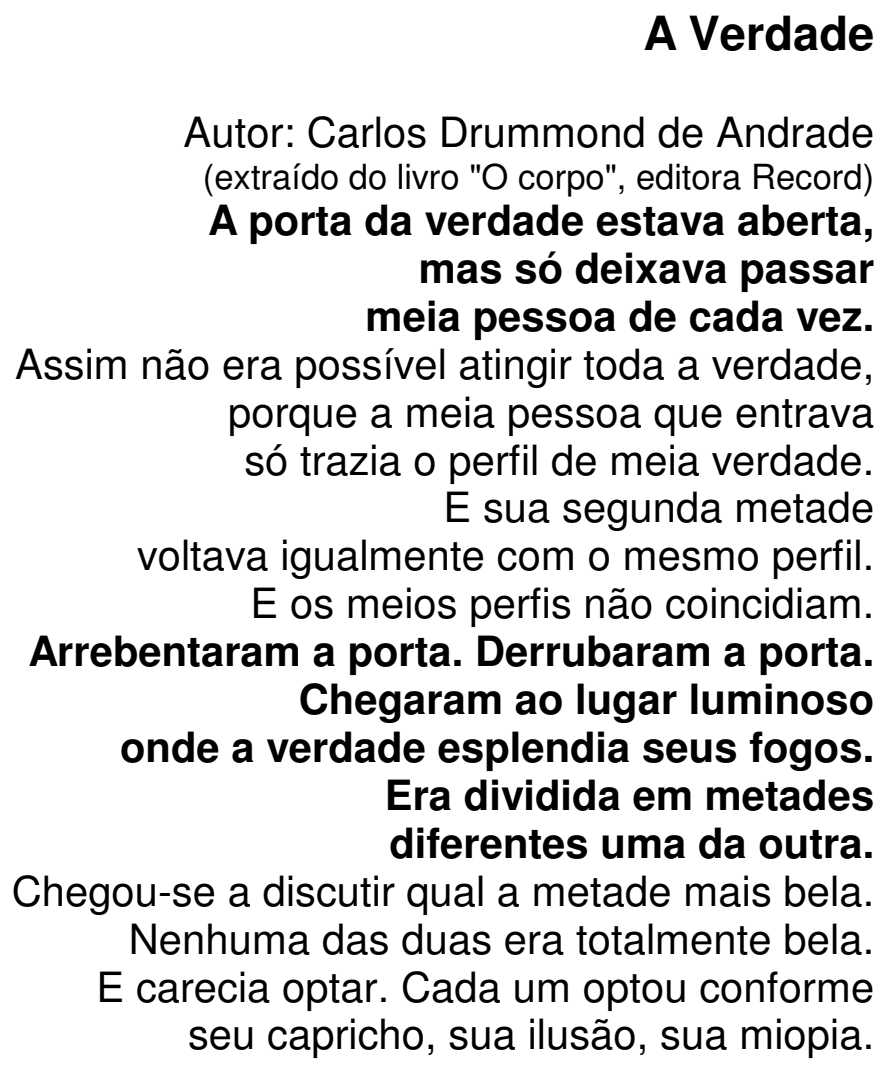

"A mais triste das vidas e a mais triste das mortes são a vida e a morte do homem que não tem coragem de morrer pelo bem, quando por ele não possa viver".

Rui Barbosa 
RESUMO

Jorge MD. A assistência domiciliária odontológica sob a perspectiva da bioética personalista [Dissertação de Mestrado]. São Paulo: Faculdade de Odontologia da USP; 2006.

\section{RESUMO}

O objetivo deste trabalho foi analisar os variados aspectos que envolvem o serviço de atendimento domiciliário odontológico, especialmente aqueles relacionados à humanização da relação profissional-paciente, ao respeito à dignidade humana quando do exercício da profissão que não em ambiente hospitalar e, ainda, os aspectos éticos relacionados a esse tipo de atividade. Ressalte-se que a presente análise não se limita a explicitar as características do serviço de atendimento domiciliário odontológico, mas dedica-se, ainda, a refletir acerca de questões bioéticas que surgem quando do exercício dessa atividade. E vai um pouco mais além, na medida em que enfoca essas questões sob a óptica do modelo personalista de bioética, que adota como ponto de partida de reflexão o ser humano enquanto pessoa única em corpo e espírito, um ser considerado na sua totalidade, pois ao mesmo tempo em que somos tão diferentes uns dos outros, somos iguais nos nossos desejos e anseios mais primitivos: viver e ser feliz.

Palavras-chave: Atendimento Domiciliário. Odontologia. Bioética. Personalismo. Humanização. 
ABSTRACT 
ABSTRACT

Jorge MD. The odontological homecare seen under personalist bioethic's perspectives [Dissertação de Mestrado]. São Paulo: Faculdade de Odontologia da USP; 2006.

\section{ABSTRACT}

The main purpose of this thesis is to analyze some of the aspects related to the odontological homecare program, specially those related to humanization of the relations between doctor and his patients, the respect to human dignity principle when dealing with a patient in non-hospital place, such as his home, and, also, the ethics aspects related to this kind of job. It is also important to mention that this whole analysis is also dedicated to study and reflect about some important bioethics issues related to the odontological homecare program, always having in mind that every Human Being is unique, as a body, a spirit, and as a person, as thought by personalist bioethics. At the same time we, all human beings, are so different from each other, but also so similar especially concerning our most primitive desires and hopes: To live and to be happy.

Key-Words: Homecare. Bioethics. Humanization. Human dignity. 


\section{SUMÁRIO}

1 INTRODUÇÃO

2 REVISÃO DE LITERATURA ........................................................... 04

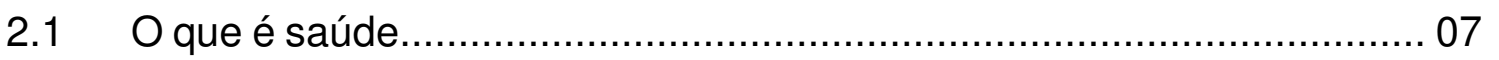

2.2 O direito à saúde............................................................... 10

2.3 O Serviço Público - noções conceituais............................................ 13

2.3.1 O Sistema Único de Saúde (SUS)................................................. 17

2.4 Histórico da Assistência Domiciliária e a importância da relação

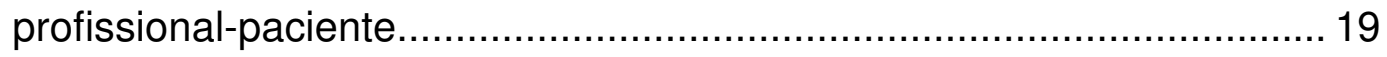

2.5 Bioética: da origem ao modelo personalista..................................... 25

3 O PROGRAMA DE ATENDIMENTO DOMICILIÁRIO......................... 31

3.1 Considerações técnicas e legais....................................................... 33

3.2 O exemplo do Programa desenvolvido pelo Hospital Universitário da Universidade de São Paulo (PAD-HU/USP) .......................................... 36

3.3 A atuação do Cirurgião-Dentista na equipe multiprofissional do PADHU/USP

3.4 O relacionamento profissional-paciente: em busca de relações mais humanas. 43

4 O ENFOQUE CONFERIDO PELA BIOÉTICA DE MODELO PERSONALISTA AO ATENDIMENTO DOMICILIÁRIO

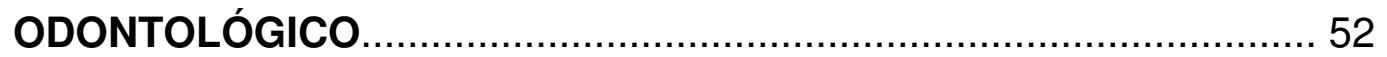

4.1 A bioética de modelo personalista: o que é e porque adotá-la............... 58

4.2 A bioética de modelo personalista e o respeito à dignidade da pessoa humana 
4.3 O personalismo e o atendimento domiciliário odontológico.................. 63

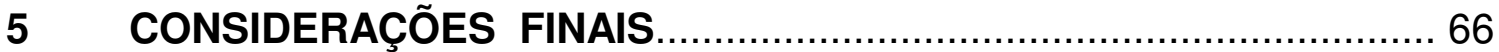

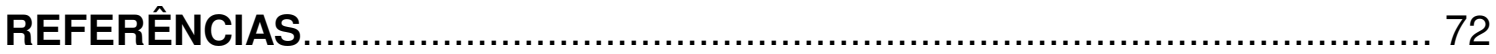

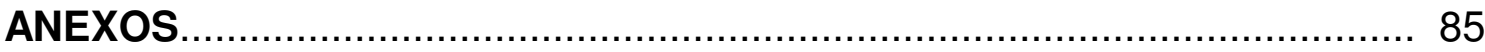




\section{LISTA DE ABREVIATURAS}

ANVISA

AVD

AVUSP

CEO

$\mathrm{CF} / 88$

CFO

DP

IBGE

$\mathrm{HU}$

MS

$\mathrm{OH}$

OMS

PACs

PAD

PED

POD

PSF

SUS

UBS

USP
Agência Nacional de Vigilância Sanitária do Ministério da Saúde

Atividades da Vida Diária

Ação Voluntária do HU/USP

Código de Ética Odontológico

Constituição Federal de 1988

Conselho Federal de Odontologia

Direito Público

Instituto Brasileiro de Geografia e Estatística

Hospital Universitário

Ministério da Saúde

Odontologia Hospitalar

Organização Mundial da Saúde

Programa de Agentes Comunitários

Programa de Assistência Domiciliária

Programa Pediátrico de assistência Domiciliária

Programa de Oxigenoterapia Domiciliária

Programa de Saúde da Família

Sistema Único de Saúde

Unidade Básica de Saúde

Universidade de São Paulo 
INTRODUÇÃO

\section{INTRODUÇÃO}

Ao longo da evolução histórica da Humanidade, e em face do progresso da sociedade brasileira, as formas de organização da produção e a distribuição espacial da população foram sendo altamente modificadas.

Esse fenômeno sócio-econômico-geográfico resultou, principalmente, da diminuição das taxas de fecundidade e de mortalidade, da redução do tamanho das famílias em geral e dos processos de industrialização e urbanização crescentes no país, essencialmente após a década de 1950. Ainda nesse período, com a implementação de políticas governamentais destinadas à prevenção e ao combate de epidemias causadas por doenças infecto-contagiosas, como o desenvolvimento da assistência à saúde e o saneamento básico - ampliação de redes de abastecimento de água e de esgoto sanitário - observou-se uma sensível diminuição dos óbitos daí resultantes, aumentando proporcionalmente a incidência de doenças crônicodegenerativas (MINAYO, 1995).

No Brasil, estima-se que a população de idosos em números absolutos triplicará entre 2000 e 2050, e é de se esperar o impacto do aumento da prevalência dessas doenças crônico-degenerativas com seus efeitos sobre a capacidade funcional e a mortalidade nos grupos afetados e na sociedade em geral (JACOB FILHO; CHIBA; ANDRADE, 2000).

As doenças crônico-degenerativas predominam na idade adulta e sua incidência, prevalência e mortalidade se elevam à medida que aumenta a expectativa de vida média da população. São, em geral, caracterizadas por uma evolução lenta e progressiva, irreversível, por um longo período de latência assintomático, exigindo constante supervisão, observação e cuidado. 
INTRODUÇÃO

Dentre as doenças crônico-degenerativas que podem passar despercebidas ou associadas a outras afecções, estão as neoplasias e as demências, que são síndromes caracterizadas por declínio intelectual a partir de um nível cognitivo mais elevado, associada as mudanças no comportamento e na personalidade, que resultam em comprometimento das capacidades psicossociais, cujo óbito é observado a longo e médio prazo.

Foi exatamente diante desse quadro composto por pacientes portadores de doenças crônico-degenerativas, famílias menores em que todos os membros precisam trabalhar fora para sobreviver e a demanda crescente por leitos de hospital, que ressurgiu a importância e a valorização dos profissionais ligados à assistência domiciliária.

$\mathrm{O}$ atendimento domiciliário é, assim, um conjunto de atividades e procedimentos que visa dar ao paciente maior conforto e melhor convívio com a doença, readaptando-o ao meio em que está mais habituado: seu domicílio.

Ademais, considerando os vários aspectos técnicos de procedimentos médico-odontológicos, de enfermagem e de apoio ao binômio paciente-cuidador, nossa atenção foi levada a contribuir para o estudo e análise do Programa de Atendimento Domiciliário com vistas à reflexão acerca das questões bioéticas que surgem quando do exercício dessa atividade, tendo como ponto fundamental de reflexão o ser humano enquanto pessoa única em corpo e espírito, e respeitado na totalidade de seus desejos.

O presente trabalho vem, portanto, exatamente de encontro a essa nova perspectiva econômico-social, que evidencia a real importância do atendimento domiciliário.

Assim, caberá ao profissional da saúde, efetuar uma análise crítica de sua atuação no domicílio do paciente que requer seus serviços, até porque, num primeiro momento, o atendimento domiciliário pode se apresentar como uma espécie de invasão de privacidade, ou seja, pode causar constrangimento do 
paciente e de sua família, motivo pelo qual se torna essencial a apresentação de tão importante atividade, especialmente diante dos fundamentos fornecidos pelo modelo personalista de bioética. 
REVISÃO DE LITERATURA

\section{REVISÃO DE LITERATURA}

... como todas as ciências, a odontologia é um lento, contínuo suceder-se de fatos e realizações, influenciados, sempre, pelos acontecimentos anteriores. (ROSENTHAL, 2001).

A fim de entender os acontecimentos relacionados ao Atendimento Domiciliário Odontológico tal qual realizado na atualidade, é necessário retomar alguns aspectos históricos relacionados à Odontologia.

Para Botazzo (2000), duas posições, entre as dispersões que o tema usualmente sugere, são encontradas com maior vigor e insistência, uma das quais está presente como senso comum: a de que a Odontologia atual é uma prática herdada de cirurgiões-barbeiros da Idade Média, e a destes do humilde praticante da Antiguidade, numa longa e intrincada sucessão; a outra consiste na reiteração do nome de Pierre Fauchard como o "Pai da Odontologia" ou o fundador da Odontologia científica moderna.

De fato, nos últimos cem anos a Odontologia passou por inúmeros progressos científicos, distanciando-se de sua origem e tornando-se uma verdadeira ciência da saúde bucal sem, contudo, desprezar o fato de que o ato de cuidar sempre esteve e sempre estará presente na História da Humanidade, principalmente no evoluir das profissões voltadas à área da saúde.

Nesse sentido, Waldow (2001), aponta para o fato de que o cuidado nasce de um interesse, de uma responsabilidade, de uma preocupação, de um afeto. É o cuidar como forma de viver e de se relacionar.

Segundo a autora, "o cuidado tecnológico, também, de certa forma, está presente nas diversas civilizações, porém de maneira indiferenciada, às vezes, das práticas de cura, ou seja, da medicina". 
REVISÃO DE LITERATURA

Anteriormente à Odontologia científica, e até mesmo à Odontologiaestética, surgiu a Odontologia-cuidado, advinda do interesse em se relacionar e cuidar dos indivíduos mais próximos. Esse interesse, por sua vez decorrente da própria necessidade dos indivíduos que requeriam cuidados, vão além do avanço tecnológico para criação de equipamentos e da criação de instrumentos sofisticados.

Novamente citando Rosenthal (2001), os primeiros cuidados odontológicos eram realizados de joelhos, com o paciente também no chão, de joelhos, "entre os persas babilônicos, os operadores continuaram de joelhos, mas com o paciente deitado no chão. Os chineses e japoneses, embora assistidos pela luz exclusiva do dia, não operavam mais a céu descoberto, porém permaneceu a posição de joelhos. (...) Em 1363, pela primeira vez, foi introduzido o termo "dentista", por Guy de Chauliac, cirurgião de Avignon, porém a figura dos 'Tiradentes' continuou típica até 1700 , trabalhando nas praças dos mercados".

Assim, a visita domiciliária, muito longe de consistir um avanço tecnológico no cuidado odontológico, revestia-se de um enfoque exclusivamente assistencialista, de caridade, cujo desenrolar será abordado nos itens subseqüentes.

Frise-se que, antes de adentrar ao tema propriamente dito e objeto da presente dissertação, é necessário que compreendamos alguns dos conceitos trabalhados pela assistência domiciliária odontológica, que vão da noção de saúde à criação da assistência domiciliária odontológica além de uma visão geral acerca do histórico da bioética, cujo enfoque personalista é de fundamental importância para a presente análise. 
REVISÃO DE LITERATURA

\subsection{O que é saúde}

"Saúde: 1. Bom estado das funções orgânicas, físicas e mentais. 2. Vigor, força, robustez. 3. Brinde.” (MINI DICIONÁRIO ..., 1996).

"Saúde: s.f. Estado do que é são ou de quem tem as funções orgânicas no seu estado normal" (TERSARIOL, 1997).

Um indivíduo com todos os órgãos e sistemas funcionando perfeitamente, emocionalmente estável, e socialmente estabilizado, mas que vive em um ambiente degradado, com águas, ar e terrenos poluídos pode ser considerado uma pessoa saudável? Ou devemos incluir, nesta definição, a harmonia com o meio ambiente e o equilíbrio com que ele se relaciona com o planeta?

Historicamente saúde tem sido definida por diversos modos. Os antigos médicos gregos acreditavam que saúde era uma condição de equilíbrio do corpo. Para os índios do Novo Mundo, estar saudável era estar em harmonia com a natureza. Os chineses antigos acreditavam que saúde era o reflexo de uma força chamada "QI" ${ }^{1}$ (BONTEMPO, 1992).

Saúde não é apenas a ausência de doença, ela corresponde ao bem estar humano nas vertentes física, psíquica, social (e, por que não, espiritual), tal como consta na definição mais conhecida, proposta pela Organização mundial da Saúde (1946).

\footnotetext{
${ }^{1}$ De acordo com a tradicional medicina oriental, o "QI" ou "CHI" - energia vital - flui por canais invisíveis que se distribuem sob a pele, chagando a todas as partes do corpo de modo a permitir a manutenção das funções orgânicas que garantem a vida. Por serem invisíveis a olho nu, esses meridianos de acupuntura eram considerados imaginários até a invenção, pelo cientista russo Kirlian, de um aparelho que os registra fotograficamente (BONTEMPO, 1992 - p.39).
} 
REVISÃO DE LITERATURA

Para alguns autores, o termo saúde procede, etimologicamente, do latim sanitas, referindo-se à integridade anátomo-funcional dos organismos vivos (sanidade). Para De Plácido e Silva (2001), entretanto, a origem etimológica do termo encontra-se na palavra latina salus, que significa conservação da vida, salvação, designando o estado de saúde, ou estado de sanidade dos seres viventes. Estar com saúde ou ter saúde, pois, é exercer normalmente todas as funções dos órgãos.

Frise-se que não se trata de conceito unívoco, contém mais de uma significação, que podem ser confundidas. Destas significações, todas empregadas com alguma freqüência em quase todas as áreas do conhecimento humano, destacam-se: a) sanidade, ausência de enfermidade em um ser vivo (o mais antigo significado, como em: esteve doente, recuperou a saúde); b) saudação amistosa (à moda dos romanos antigos); c) rito verbal exclamativo, quando alguém espirra; d) estado de capacidade, energia, disposição e vigor físico ou mental (como em não tenho saúde para esse trabalho), sentido figurado e metafórico; e) sentir-se bem ou, ao menos, não se sentir mal (a saúde se manifesta no silêncio dos órgãos, diziam os antigos); f) área do conhecimento e campo de estudo sobre a saúde, as ciências da saúde (enfim, todos os estudos sanitários que se interessam pelos indivíduos e comunidades, as ciências da saúde); g) designação sintética dos programas, estabelecimentos, agências ou organismos sociais públicos ou privados destinados a Cuidar da saúde dos indivíduos e comunidades; h) atividade política pública ou programa social governamental voltado para os cuidados com a saúde individual ou coletiva e para a administração destes serviços (como em funcionários e profissionais da área da saúde, Ministério da Saúde e Secretaria de Saúde).

$\mathrm{Na}$ atualidade, saúde tem sido definida não apenas como a ausência de doenças, mas como uma multiplicidade de aspectos do comportamento humano voltado a um estado de completo bem-estar físico, mental e social. 
REVISÃO DE LITERATURA

Por outro lado, saúde constitui-se, também, em um dos direitos sociais previsto constitucionalmente, cabendo a todos os entes da federação, concorrentemente, legislar sobre o tema a fim de garantir à população um acesso universal e igualitário a todos os serviços voltados á área da saúde (DE PLÁCIDO E SILVA, 2001).

Com o passar do tempo e o evoluir das políticas públicas voltadas à área da saúde, vislumbrou-se a necessidade de mudar o foco de aplicação de recursos, colocando-se em evidência o modelo preventivo e de promoção da saúde, constitucionalmente estabelecido em 1988, com Sistema Único de Saúde (SUS) (GONÇALVES, 2005).

Em decorrência dessa alteração de enfoque, como não poderia deixar de ser, tornou-se necessário também mudar a forma de atuação do Estado, que passou a preocupar-se com a melhoria da infra-estrutura para os povos.

Tal preocupação tornou-se evidente quanto à moradia, saneamento básico e qualidade de vida, melhoria das condições sociais, de empregabilidade e eqüidade na educação, e a disponibilidade de serviços de saúde organizados hierarquicamente de forma a atender o cidadão em todas as suas necessidades, com gratuidade, totalidade, ética e eqüidade, além de uma eficiente política de imunização de qualidade, com vacinas seguras e testadas, e o fornecimento de medicamentos essenciais para o tratamento das principais doenças prevalentes numa determinada região (ARAÚJO, 2004).

Com essa atuação inovadora do Estado consubstanciada na criação do SUS, a situação da saúde no Brasil passou por inegáveis avanços nos últimos dez ou mais anos. Muitos problemas, que tradicionalmente estiveram na pauta das discussões e prioridades da saúde pública, evoluíram favoravelmente, porém, novos desafios somaram-se aos antigos, exigindo providências para as quais a utilização de dados é essencial.

Dentre as novas problemáticas, surgem as questões relacionadas à bioética como, por exemplo, quais os princípios e valores que devem embasar a 
tomada de decisões pelo gestor da saúde quando da realização de políticas públicas ou, ainda, questões relativas à humanização do atendimento nos serviços públicos ligados à saúde, e em especial no atendimento domiciliário odontológico, objeto do presente trabalho, em vista de princípios bioéticos que visam resguardar a pessoa humana em sua inteireza.

\subsection{0 direito à saúde}

Conforme já observado, o direito à saúde é parte de um conjunto de direitos chamados de direitos sociais, que têm como inspiração o valor da igualdade entre as pessoas.

No Brasil, esse direito apenas foi reconhecido expressamente na Constituição Federal de 1988. Antes disso, o Estado apenas oferecia atendimento à saúde para trabalhadores com carteira assinada e suas famílias, as outras pessoas tinham acesso à estes serviços como um favor e não como um direito. Durante a Constituinte de 1988 as responsabilidades do Estado são repensadas e promover a saúde de todos passa a ser seu dever:

A saúde é direito de todos e dever do Estado, garantido mediante políticas sociais e econômicas que visem à redução do risco de doença e de outros agravos e ao acesso universal e igualitário às ações e serviços para a promoção, proteção e recuperação. (BRASIL, 1988, ARTIGO 196).

O excerto mencionado somente na Carta de 1988 evidência, assim, que o direito à saúde - e os direitos sociais em geral - não foram sempre reconhecidos e aceitos pelo Estado Brasileiro. Ao contrário, nas primeiras lutas pelos direitos sociais, o Poder Público acabou por se colocar ao lado da minoria que detinha o poder econômico no país. José Murilo de Carvalho afirma que ficou notória a frase de um presidenciável de que a questão social o 
REVISÃO DE LITERATURA

nome genérico do problema operário - era questão de polícia (CARVALHO, 2002.

Nas décadas anteriores a 1988, portanto, necessitar de ajuda ou cooperação social convertia-se em estigma pessoal antes que sugestão de que a nova forma de organizar a produção não era satisfatória. As políticas governamentais eram fundamentadas no fato de que "os homens são desiguais (...) e a distribuição de benefícios econômicos e sociais reflete essa desigualdade, através do mercado, e nenhuma ação pública, tendo por objetivo escamotear esse duro fato é legítima" (SANTOS, 1979).

Com o advento da Constituição de 1934, pode-se dizer que houve um avanço no reconhecimento da maioria dos direitos sociais mais difundidos na época, ainda que com muitas restrições, principalmente no tocante ao trabalho, entre eles: a isonomia salarial, o salário mínimo, a jornada de trabalho de 8 horas; a proibição do trabalho de menores, o repouso semanal, as férias remuneradas, a indenização por dispensa sem justa causa, a assistência médica ao trabalhador e à gestante, bem como reconheceu a existência dos sindicatos e associações profissionais, estabelecendo-se, ainda, a submissão do direito de propriedade ao interesse social ou coletivo, entre outras medidas.

As posturas de política social na época eram concebidas como privilégio e não como direito, já que uma série de trabalhadores (todos os autônomos e, principalmente, as trabalhadoras domésticas) ficava à margem dos benefícios concedidos pelo sistema previdenciário da época. Os direitos sociais de cidadania então reconhecidos não foram resultados, portanto, da luta política dos movimentos sociais organizados; antes era resultado da benevolência do Estado, mormente daquele que chefiava o Poder Executivo e seus órgãos (CARVALHO, 2002).

Essa concepção perdurou até a promulgação da Constituição Federal de 1988, que consolidou a existência dos direitos sociais, como o direito à saúde, desvinculados de qualquer ato de benevolência do Estado, e estendidos a todo e qualquer cidadão brasileiro, sem distinção de qualquer gênero. De fato, consta do artigo 194 da Carta Magna o conceito de 
seguridade social, consubstanciado num conjunto integrado de ações, de iniciativa dos Poderes Públicos e da sociedade, destinadas a garantir os direitos relativos à saúde, previdência e assistência social (GONÇALVES, 2005).

No que tange ao direito à saúde assegurado pelo artigo 196 da $\mathrm{CF} / 88$, cumpre ressaltar que ele não deve ser lido apenas como uma promessa ou uma declaração de intenções, mas como um direito fundamental do cidadão e que tem aplicação imediata, isto é, pode e deve ser cobrado. A saúde é um direito de todos porque sem ela não há condições de uma vida digna, e é um dever do Estado porque é financiada pelos impostos que são pagos pela população.

A universalidade é a nota característica desse subsistema [saúde], que é dirigido a toda e qualquer pessoa que dele necessite. Não se limita à prestação de serviços de recuperação, visto que o conceito constitucional é bem mais amplo, dando inclusive ênfase à prevenção do risco, através de políticas sociais e econômicas. O conceito de saúde não se restringe ao indivíduo, mas alcança todo o corpo social (BALERA, 1989).

Desta forma, e para que o direito à saúde seja uma realidade, é preciso que o Estado crie condições de atendimento em postos de saúde, hospitais, programas de prevenção, medicamentos, etc., além de assegurar que $o$ atendimento seja universal (atingindo a todos os que precisam) e integral (garantindo tudo o que a pessoa precise).

Nesse sentido, a criação de um programa de atendimento domiciliario ligado ao Sistema Único de Saúde - SUS, que será abordado com mais cuidado no decorrer do presente trabalho, está diretamente relacionada à tomada de responsabilidade por parte do Estado. 


\subsection{0 serviço público - noções conceituais}

Trabalhosa a tarefa de conceituar serviço público, vez que sua definição sofreu relevantes transformações no tempo, tanto no que se refere aos seus elementos constitutivos quanto aos de sua abrangência. Todavia importante fazer algumas considerações acerca do tema na medida em que o atendimento domiciliário odontológico nada mais é do que uma prestação de serviços públicos ligados à área da saúde e que deve, por assim dizer, obedecer e submeter-se às leis, regras e princípios norteadores das atividades típicas da Administração Pública.

Inicialmente, três critérios eram adotados para a definição de serviço público, embora se desse maior ou menor ênfase ora a um, ora a outro: (1) o critério subjetivo, que leva em consideração a pessoa jurídica prestadora da atividade, o que, no caso do serviço público, seria o Estado; (2) o critério material, considerando a atividade exercida, sendo que o serviço público seria caracterizado pela atividade cujo escopo é a satisfação de necessidades coletivas; e (3) o critério formal, levando-se em consideração o regime jurídico a que se submete a atividade, sendo que o serviço público seria aquele sob regime de direito público derrogatório e exorbitante do direito comum (DI PIETRO, 2002).

Com o evoluir da civilização humana, Di Pietro (2002) houve por bem conceituar serviço público como sendo toda atividade material que a lei atribui ao Estado para que a exerça diretamente ou por meio de seus delegados, com o objetivo de satisfazer concretamente as necessidades coletivas, sob regime jurídico total ou parcialmente público.

Bandeira de Mello (2001) entende que determinadas atividades, cujo escopo é satisfazer a coletividade em geral, tornam-se serviços públicos quando, em dado tempo e lugar, o Estado considera correto não relegá-las à livre iniciativa, devido à importância dessas atividades, como as relacionadas à área da saúde, 
colocando-as sob a disciplina de Direito Público, de modo a resguardar os interesses objetivados na atividade em questão.

Nesse sentido, o autor conceitua serviço público como toda atividade de oferecimento de utilidade ou comodidade material destinada à satisfação da coletividade em geral, mas fruível singularmente pelos administrados, que o Estado assume como pertinente a seus deveres e presta por si mesmo ou por quem Ihe faça às vezes, sob um regime de Direito Público - portanto, consagrador de prerrogativas de supremacia e de restrições especiais instituído em favor dos interesses definidos como públicos no sistema normativo.

Corroborando com esse entendimento, e ajudando a eliminar dúvidas acerca do que venha a ser o serviço público para o correto entendimento do presente trabalho, Derani (2002) afirma que "Serviço Público é uma atividade de interesse coletivo, de natureza econômica ou não, decorrente do exercício do Poder Público, fundado na solidariedade social e objetiva coesão social". A autora entende que o serviço público é caracterizado por três elementos: (1) a continuidade do serviço; (2) a universalidade geográfica da prestação; e (3) a eqüidade no tratamento dos usuários, compatível com as imposições financeiras, econômicas e sociais.

Medauar (2000), por sua vez, afirma que o serviço público refere-se à atividade prestacional, pela qual o poder público propicia algo necessário à vida coletiva, como água, energia elétrica e transporte urbano. Nesse sentido, as atividades meio, tais como a de arrecadação de tributos, não poderiam ser consideradas como serviço público.

No Brasil, a Constituição Federal de 1988 determinou quais atividades serão consideradas serviço público, partilhando tais atividades entre a União, os Estados, o Distrito Federal e os Municípios.

Assim, consoante o artigo 21, são serviços públicos pertencentes à União os serviços postais e de correio aéreo nacional, telecomunicações, radiodifusão, energia elétrica, navegação aérea, aeroespacial, infraestrutura aeroportuária, transporte ferroviário e aquaviário entre portos brasileiros e fronteiras nacionais, ou que transponham os limites de Estado ou 
Território, transporte rodoviário interestadual e internacional de passageiros, exploração dos portos marítimos, fluviais e lacustres ${ }^{2}$.

Aos Estados, o artigo 25, § 1ํㅡㄹ da Lei Magna, estabelece que caberão aos serviços públicos não reservados à União e aos Municípios, como o transporte coletivo intermunicipal, além da exploração dos serviços locais de gás canalizado, na forma da lei.

Por fim, aos municípios caberiam os serviços públicos de interesse local, inclusive o transporte coletivo, que possui caráter essencial, nos termos do artigo 30, inciso V, da Lei Magna.

Vale ressaltar que há serviços comuns aos diferentes entes políticos, como a assistência pública, a saúde e a proteção e garantia das pessoas portadoras de deficiência.

Outro ponto que merece ser tratado relaciona-se ao fato de que os serviços públicos, submetidos ao regime de Direito Público, devem observar determinados princípios de modo a garantir que as necessidades coletivas sejam atendidas. São preceitos fundamentais que se aplicam independente do modo de exercício do serviço público, permitindo que os mesmos sejam regidos por outras normas e princípios específicos, peculiares à atividade em questão.

Esses preceitos visam assegurar a qualidade do serviço, oferecendo garantias aos usuários. Assim, em que pese os autores divergirem quanto ao número, denominação e conteúdo dos princípios inerentes ao regime jurídico do serviço público, adotaremos para o desenvolvimento do presente trabalho, a indicação fornecida por Di Pietro (2002).

A autora entende serem inerentes ao regime jurídico dos serviços públicos basicamente três princípios. O primeiro consiste no preceito da continuidade, ou seja, que o serviço não pode parar, dada a sua importância. Tal princípio traz como conseqüências a imposição de prazos rigorosos ao

\footnotetext{
${ }^{2}$ A Lei Federal $\mathrm{N}^{\circ} .074 / 95$, por sua vez, estabelece como serviços públicos federais os de barragens, contenções, eclusas, diques e irrigações.
} 
contratante, a inaplicabilidade da exceptio non adimpleti contractus ${ }^{3}$ contra a Administração e ainda, o reconhecimento de privilégios para a Administração quando necessário para dar continuidade à execução do serviço.

O segundo princípio consiste na mutabilidade do regime jurídico ou da flexibilidade dos meios aos fins, de forma a autorizar mudanças no regime de execução do serviço, adaptando-o ao interesse público. Desse preceito decorre a não existência de direito adquirido à manutenção de determinado regime jurídico para os servidores públicos, os usuários desses serviços ou os contratados da Administração.

Já o terceiro princípio consiste na igualdade dos usuários perante o serviço público, de modo que toda pessoa fará jus à prestação do serviço, uma vez satisfeitas as condições legais, não havendo qualquer distinção de caráter pessoal.

Esses princípios não são taxativos e deles podem decorrer (e de fato decorrem) outros relacionados à prestação de serviços públicos, tais como os princípios da universalidade e impessoalidade no atendimento, a regularidade, a neutralidade, obrigatoriedade, eficiência, responsabilidade, etc. como bem observado por Bandeira DE Mello (2001) e Grotti (2000).

Frise-se, por fim, que todos esses princípios relacionam-se diretamente à prestação de todo e qualquer serviço público prestado pelo Estado, incluindo aqueles ligados à área da saúde, como o programa de saúde da família (PSF) ou, ainda, o programa de atendimento domiciliário, como o prestado pelo Hospital Universitário da Universidade de São Paulo (PAD-HU), a ser devidamente abordado no decorrer desta dissertação.

\footnotetext{
${ }^{3}$ A exceptio non adimpleti contractus, ou exceção de contrato não cumprido, se acha consagrada no artigo 476 do Código Civil de 2002 nos seguintes termos: "nos contratos bilaterais, nenhum dos contratantes, antes de cumprida a sua obrigação, pode exigir o implemento da do outro".
} 
REVISÃO DE LITERATURA

\subsubsection{O Sistema Único de Saúde (SUS)}

Está escrito na Constituição Federal de 1988: "todos são iguais perante a lei, sem distinção de qualquer natureza" (art. 5ํ da CF/88). Na prática, entretanto, não é bem assim que as coisas funcionam, e as desigualdades sociais no Brasil atingem proporções gigantescas (BRASIL,1988).

A grande extensão territorial do país e a diversidade de realidades populacionais tornam difícil a aplicação à risca do que está estabelecido na Constituição, o que enseja os seguintes questionamentos: Pode haver igualdade onde a pobreza absoluta convive com a riqueza ostensiva? $\mathrm{Na}$ área da saúde esse preceito tem sido exercido de forma plena?

Cabe-nos, primeiramente, contextualizar o âmbito de criação e regulamentação do SUS para, num segundo momento, entender seu papel no que tange à promoção da saúde e do atendimento domiciliário odontológico.

De fato, a saúde, no Brasil, estrutura-se através de um sistema unificado e hierarquizado denominado Sistema Único de Saúde - SUS - que é financiado por meio de recursos de orçamentos públicos e contribuições sociais. O artigo 198 da CF/88, com redação dada pela Emenda Constitucional no. 29 , de 13 de setembro de 2000, remete à lei complementar a fixação de limites mínimos de recursos orçamentários que deverão ser aplicados em ações e serviços públicos de saúde. A Carta Magna ainda prevê que a assistência à saúde é livre iniciativa privada, que poderá também participar do SUS, de forma complementar, mediante contrato público ou convênio, tendo preferência as entidades filantrópicas e as sem fins lucrativos. Veda, entretanto, a destinação de recursos públicos para auxílios ou subvenções a instituições privadas com fins lucrativos (GONÇALVES, 2005). 
REVISÃO DE LITERATURA

De acordo com a Lei no. 8.080/90, integram o SUS: o Ministério da saúde; as Secretarias de Saúde dos Estados. Do Distrito Federal e dos Municípios; os Consórcios Administrativos Intermunicipais, quando formalizados; os hospitais locais, regionais e especializados, incluídos os hospitais universitários; os laboratórios públicos de saúde e hemocentros e os distritos municipais de saúde; os postos de saúde; os centros de saúde; as unidades mistas; os ambulatórios de especialidades; a Fundação Nacional de Saúde; a Fundação Oswaldo Cruz; o Instituo Nacional do Câncer (BALERA, 1989).

Melo (2004), por sua vez, afirma que após o incontestável avanço da constitucionalização do Sistema Único de Saúde (SUS) é necessária sua consolidação, que se dará por meio de políticas públicas que garantam à população o acesso universal e igualitário aos serviços de saúde.

Para Souza (1998), o Ministério da Saúde tem estimulado, com algum atraso em relação à atuação mundial na área, a criação de programas de saúde com equipes que fazem visitas domiciliarias, também atuando na saúde bucal.

Segundo o autor, promover a assistência à saúde é muito importante, incluindo aí a saúde bucal, uma vez que a cárie é uma doença contaminante e pode ser transmitida para outra pessoa, sendo o seu controle fundamental, uma vez que a bactéria no sangue pode até provocar septicemia e a pessoa vir a óbito pela falência múltipla dos órgãos.

Ademais, a origem de programas que visam levar a saúde em casa não é recente. Souza (1998) afirma que a experiência remonta outras de cunho mundial como as do Canadá, Inglaterra e Cuba, cujo programa integra o médico de família, a visita domiciliar e as equipes específicas para as comunidades. A idéia, segundo ele, é simples e trabalha com a lógica preconizada pelo Sistema Único de Saúde (SUS), que é garantir acesso e integralidade.

Dessa forma, o acesso da comunidade é universal, sem nenhuma barreira, nada que impeça o usuário de acessar as ações ou serviços de 
REVISÃO DE LITERATURA

saúde. Integralidade, por sua vez, significa atender as pessoas no meio onde elas vivem, como seres humanos completos, dentro do seu contexto, de sua família e de sua comunidade, evitando sua fragmentação em especialidades e em órgãos, como o nossa formação cartesiana nos leva a fazer.

Carvalho e Santos (1992), por sua vez, afirmam que por melhor estruturado que venha a ser o SUS, este não funcionará a contento e os ideais nele traduzidos estarão fadados ao fracasso se não dispuser de recursos humanos qualificados.

Como as ações de saúde somente ocorrem quando da interação entre profissional-paciente, a importância dos recursos humanos é indiscutível (ARAÚJO, 2004).

De qualquer forma, temos que estabelecer uma atenção básica resolutiva e de qualidade integrada aos demais níveis, a fim de reafirmar, na prática, os princípios constitucionais da universalidade, da eqüidade e da integralidade das ações estabelecidas no SUS (MELO, 2004).

\subsection{Histórico da assistência domiciliária e a importância da relação profissional-paciente}

Para Duarte e Diogo (2000), a assistência à saúde vem sofrendo modificações importantes nas últimas décadas e, em especial, em nosso país. $O$ atendimento domiciliário surge como um dos modelos de atenção à saúde já consolidado em alguns países desenvolvidos e com rápido e expressivo crescimento no Brasil. No entanto, sua prática remonta a era a.C., quando a caridade e a solidariedade eram seu alicerce.

O desenvolvimento tecnológico, a escassez de recursos na área da saúde e, principalmente, as alterações demográficas e o aumento da demanda, são fatores que contribuíram sensivelmente para o incremento do atendimento domiciliário a idosos, uma vez que nesta faixa etária, o comprometimento da 
REVISÃO DE LITERATURA

independência decorrente das doenças crônico-degenerativas, pode resultar em necessidade de cuidados.

Segundo Ceschini (2002), há mais de quarenta anos o doente era cuidado em casa, mas com a especialização e a evolução da medicina e recursos de saúde, a família foi perdendo esse espaço.

A própria condição e as características das famílias foram se alterando com as mudanças da sociedade. De acordo com a autora, um aspecto importante da sociedade está sendo modificado: o envelhecimento populacional.

Com o avanço da medicina e a melhoria da infra-estrutura (água tratada, esgoto etc.), a população passou a gozar de uma qualidade de vida muito melhor, de modo que o tempo de vida foi se prolongando e, hoje em dia, há um número muito maior de idosos. "Todos os campos da sociedade sentem a necessidade de uma atenção voltada às características e até mesmo exigências dessa população. (...) Constatando o evoluir da sociedade, novas formas de trabalho e atendimento de saúde vêm sendo desenvolvidas e até mesmo resgatadas a fim de darem apoio e resolutividade à população que dela necessitar. A assistência domiciliária surge nesse panorama, como uma das alternativas para otimizar a utilização dos recursos de saúde, e vem se tornando uma tendência mundial." (CESCHINI, 2002).

A assistência domiciliária é uma modalidade de atenção à saúde pela qual uma equipe multiprofissional realiza suas ações no próprio local de moradia do paciente, visando sua recuperação, estabilização do quadro clínico e/ou reabilitação bio-psico-social. Objetiva a melhoria da qualidade de vida, realiza treinamento do cuidador e atua numa perspectiva de prevenção e promoção da saúde (ALBUQUERQUE, 1996, 1997; CARLETTI; REJANI, 1996; SANTOS, 1979, 2001).

Albuquerque (1996) cita que em 1780 o hospital da cidade de Boston instituiu o primeiro programa de atendimento domiciliário que incluía 0 assistente social como membro integrante da equipe multiprofissional. 
REVISÃO DE LITERATURA

No Brasil, Duarte e Diogo (2000) citando Cunha (1991), observam que esta prática iniciou-se em 1919 quando foi criado o Serviço de Enfermeiras Visitadoras no Rio de Janeiro.

Albuquerque (1996) cita a criação do programa de assistência domiciliar do Hospital do Servidor Público Estadual em São Paulo no início da década de 80, a Secretaria de Higiene de Santos, em 1992, e o da Volkswagem do Brasil, em 1994.

A assistência domiciliária é mencionada na Política Nacional de Saúde do Idoso, que traz orientações acerca da forma como o idoso deve ser tratado no seu domicílio, enfatizando um tratamento que contenha "orientação, informação e assessoria de especialistas". Menciona a atenção que deve ser prestada ao cuidador por ser esta a pessoa que desenvolve uma atividade cansativa, desgastante e com riscos à sua própria saúde, e ressalta que a assistência domiciliaria deve ser, obrigatoriamente, uma alternativa para o idoso que necessita de internação hospitalar prolongada, visando à diminuição de custos das internações (BRASIL, 1999) ${ }^{4}$.

Os critérios de elegibilidade de novos pacientes podem variar na mesma proporção em que variam os serviços, sendo os mais comuns: quadro clínico que permita o atendimento no domicílio, existência de cuidador domiciliar, condição de moradia adequada e residência na área de abrangência do programa (JACOB FILHO; CHIBA; ANDRADE,2000; KASSAB, 2000; MONTEIRO e MONTEIRO, 2000; PAPALÉO NETTO; TIEPPO, 2000; YUASO; SGUIZZATTO, 2000).

\footnotetext{
4 Todo esse crescimento da assistência domiciliaria tem levado setores públicos a privados a irem em busca de sua regulamentação legal. Em 14/10/2003, foi disponibilizada na internet, no site da Agencia Nacional de Vigilância Sanitária (ANVISA), Consulta Pública $\mathrm{n}^{\circ} 81$ que, dentre outros aspectos, conceitua terminologias utilizadas na área, define os critério para admissão de pacientes e cria regras de funcionamento dos serviços de assistência domiciliar. Vide: http://www.saúde.gov.br/programas/pacs/pst.htm, de 05/05/2004.
} 
Essa prática assistencial começou a ser realizada por profissionais que demonstravam interesse e aceitação, os quais levados por experiências internacionais ou outras regionais em nosso país, implementaram o atendimento domiciliário, apesar das dificuldades, especificamente no que diz respeito à literatura nacional sobre o assunto, ainda muito escassa.

Veras (2002), por sua vez, ressalta que "cuidar em casa" não é exatamente uma novidade; tampouco deve ser tratado como modismo, mas sim como uma modalidade mais contemporânea de cuidar.

Dal Ben (2003) buscou definir assistência domiciliaria como sendo "aquela exercida por profissionais da saúde no Brasil, e que se caracteriza pelo retorno do paciente à sua residência, e que é rotulado genericamente em língua inglesa como home care".

Para Mazza (1994) partimos da definição de que ela (assistência domiciliária) é um instrumento de assistência à saúde com o objetivo de prestar atendimento no domicílio, orientar, educar, levantar possíveis soluções de saúde, fornecer subsídios educativos para que os indivíduos, a família e comunidade tenham condições de se tornarem independentes.

Santos (1979) prefere o termo "cuidado domiciliar", em face da conotação de responsabilidade, zelo, processo interativo que desenvolve a ação, atitudes e comportamento com base no conhecimento científico, sendo, portanto, de significado mais abrangente do que atendimento.

A própria palavra atendimento, segundo o Tersariol (1997), deriva de o verbo atender que significa dar ou prestar atenção, considerar, anuir, levar em conta ou, ainda, ter em vista.

Observamos, assim, que mesmo em face de tantos conceitos acerca do que venha a ser o atendimento domiciliário, o atendimento odontológico domiciliário, entretanto, não possui clara definição no âmbito das Ciências Odontológicas, até porque é pouco difundida entre os Cirurgiões-Dentistas, cabendo aos profissionais de outras áreas, mais familiarizados com essa prática assistencial, a definição do que venha a ser e os termos e expressões decorrentes dessa prática assistencial. 
REVISÃO DE LITERATURA

Vale ressaltar que no presente trabalho referimo-nos, ao atendimento domiciliário odontológico público, sem equipamentos odontológicos, e não ao atendimento domiciliário particular que utiliza um equipamento móvel ${ }^{5}$.

Quanto à importância conferida à relação profissional-paciente, para Gomes (2003) trata-se de uma relação (interpessoal) humana cuja prioridade é a promoção da saúde. É o (um) momento (mais) dramático, rico e denso no contexto das atividades sociais que tem como características principais a aplicação de técnicas, conhecimentos e habilidades pelo médico (agente de saúde) como provedor de saúde em favor do semelhante e, sempre em nome do bem. Como bem, é fazer ao próximo o que se espera receber do próximo.

Para Martins (2001), o profissional da saúde que desenvolve atividade assistencial (médico, enfermeiro, fonoaudiólogo, psicólogo, fisioterapeuta, odontólogo, nutricionista, terapeuta ocupacional, assistente social e outros), além das ações e procedimentos técnicos ligados à sua área específica, estabelece, sempre, com as pessoas que atende, relações interpessoais.

Para a autora, assim como a preocupação com a qualidade técnica faz com que, em cada área, se desenvolvam temas específicos, que constituem parte do que chamamos de conhecimentos e habilidades relativos à área técnica, a abordagem da qualidade internacional também torna necessário o estudo de vários temas teóricos e a reflexão sobre o desenvolvimento de atitudes.

Timi (2003) escreve que a relação médico-paciente remonta a épocas muito anteriores à medicina como conhecemos nos dias atuais.

O cuidar sempre esteve presente na história humana. O cuidar como forma de viver, se relacionar. O cuidado tecnológico também, de certa forma, está presente nas diversas civilizações, porém de maneira indiferenciada, às

\footnotetext{
${ }^{5}$ Há no mercado equipamentos especiais para atendimento domiciliário particular (home care).
} 
vezes, das práticas de cura, ou seja, de medicina. O cuidar sempre fez e ainda faz parte da medicina (ou deveria fazer), com a única diferença que sua ênfase atual está no procedimento, na tarefa e, obviamente, visando a um objetivo, um resultado: a cura (WALDOW, 2001).

Essas relações devem destacar-se pela presença do elemento 'confiança'; este é um elemento básico ao estabelecimento da relação de ajuda. A confiança baseia-se na constância da atitude, fato este mais relacionado ao saber-estar e à experiência de vida do que com o saber-fazer e o conhecimento intelectual (DUARTE; DIOGO, 2000).

Para Berger (1995), a relação de ajuda é antes de tudo um encontro. O profissional deve programar-se para tanto no sentido de estar aberto a esta nova interação. Ser afetuoso, mostrar-se disponível, eliminar barreiras prévias à relação, estar disposto a aceitá-lo, respeitar seu próprio meio são pontos básicos a

serem considerados no primeiro encontro com o paciente/cliente. Consideração positiva significa aceitação do outro. Parece óbvio que uma relação de ajuda como a verificada entre o profissional da saúde e o paciente - pressupõe a aceitação do outro, porém num sentido de crescimento e realização. Aceitar o outro é acreditar em seu valor e em sua dignidade sem fazer juízos morais sobre seu comportamento.

Ocorre, entretanto, que se pode prever que esta relação caminha desenfreadamente para a desumanizarão, voltando o paciente a ser, como duzentos anos atrás, um simples cliente, e nessa condição, receber a assistência médica como impessoal embora cada vez mais tecnicamente eficiente (ISMAEL, 2002). Segundo Ismael (2002), a medicalização da vida, conseqüência do progresso científico, remete a um tema de crescente importância decorrente do campo da ética enquanto código moral que regula questões que envolvem direta e indiretamente o respeito ao indivíduo: a bioética.

Assim, o modelo bioético personalista, ou Personalismo Ontologicamente Fundado nos propõe um fundamento: A pessoa humana, considerada em sua essência, em sua natureza, em sua verdade. 
O Modelo Personalista considera que a pessoa humana é composta por uma unicidade, representada pela unidade entre corpo e espírito, que constitui a sua singularidade ou identidade. A pessoa é, antes de tudo, um corpo espiritualizado, um espírito encarnado, que vale por aquilo que é e não somente pelas escolhas que faz (SGRECCIA, 2003), conforme trabalhado a seguir.

\subsection{Bioética: da origem ao modelo personalista}

A Biologia é, talvez, o campo em que os conhecimentos, nos últimos decênios, mais têm evoluído e provocado, em conseqüência, uma instigante discussão que vem sendo sob o nome de Bioética (BOFF, 2002).

Ética é um termo genérico para várias formas de se entender e analisar a vida moral. Algumas abordagens da ética são normativas (isto é, apresentam padrões de ações boas ou más), outras são descritivas (relatando aquilo em que as pessoas acreditam e como elas reagem) e outras, ainda, analisam os conceitos e métodos da ética (BEAUCHAMP; CHILDRESS, 2002).

Segundo Beauchamp e Childress (2002), a ética biomédica experimentou, desde a época de Hipócrates, uma notável continuidade, até que suas duradouras tradições começassem a ser suplantadas, ou ao menos suplementadas, por volta do início do século XX.

Para Segre (1995), esta nova área nada mais é do que ramo da ética aplicada, voltada para a reflexão sobre valores inerentes à vida e à saúde humanas, abrange os mais diversos posicionamentos com relação a mesmas situações, ensejando divergências pouco freqüentemente superadas pelo diálogo, que pode evoluir para a discussão áspera e até para o conflito. 
Segundo o autor, é utópico (e mais, desinteressante) pensar uma Bioética monolítica, que pudesse ser aceita por todos.

Conforme bem observado por Schramm (2002), o neologismo Bioética foi provavelmente criado pelo oncologista norte-americano Van Rensselaer Potter, em 1970.

Em 1971 Potter publicou Bioethics. Bridge to the future (Englewood Cliffs, N.Y., ed. Prentice-hall), no qual denunciava a periculosidade da fratura entre a cultura científica e a cultura humanística, mais especificamente: a separação entre valores morais e fatos biológicos, e propunha uma scientia nova capaz de utilizar os conhecimentos biológicos, ecológicos, genéticos e fisiológicos como guia para a ação em prol da sobrevivência humana, (SCHRAMM,2001).

Para Bellino (1997) o objeto material da bioética (a vida no sentido mais lato: vida humana pessoal e vida não-pessoal compreendem todos os organismos capazes de sentir prazer e/ou dor - os animais - e também o ambiente em geral) é comum a todas as ciências que estudam a vida. Essas ciências, por sua vez, se distinguem pelo ponto de vista formal, de como analisam seu objeto. A bioética estuda, epistemologicamente, o seu objeto sob o ponto de vista ético.

Ramos $^{6}$ (2001) destaca que um importante aspecto da bioética é que ela não está restrita às Ciências da Saúde. Esse é o verdadeiro enfoque da bioética: interdisciplinar. Quer dizer, algo diferente do que é o multidisciplinar, que conhecemos muito bem das nossas tradições universitárias, principalmente no Brasil. Multidisciplinar é sinônimo de um amontoado de diferentes profissionais, de diferentes formações, que não interagem entre si. Nesse modelo esses profissionais apenas empurram 0 problema um para o outro. A bioética tem uma proposta interdisciplinar de integração entre as disciplinas. Alguns autores ainda sugerem o termo

\footnotetext{
${ }^{6}$ Fundamentos e princípios da bioética. Conferência proferida em 31/05/01 na universidade Federal de São Paulo.
} 
"transdisciplinar", que requer uma unificação conceitual entre as disciplinas (informação verbal).

Historicamente, afirma Bellino (1997), na bioética a busca pelos princípios ocupou um lugar predominante nestes últimos vinte anos, até determinar, como escreve Warren Reich, o paradigma da bioética, sobretudo na área anglo-americana ${ }^{7}$.

Segundo o autor, foram identificados, sobretudo, três princípios fundamentais: autonomia (autodeterminação), beneficência (o maior bem do paciente), e a justiça (a distribuição equânime de benefícios e obrigações da sociedade). Também o Personalismo ${ }^{8}$ deu sua contribuição, enunciando os seguintes princípios: princípio de defesa da vida física, princípio de liberdade responsabilidade, princípio da totalidade ou princípio terapêutico, e princípio da sociabilidade e subsidiariedade.

Espinosa (1998) afirma que a mentalidade que vem produzindo os abusos que vimos na atualidade provém, na sua maior parte, de três "modelos éticos" principais que, para efeitos práticos, serão chamados de modelo liberalradical, modelo pragmatista e modelo sociobiológico.

O modelo liberal-radical, segundo o autor, remonta ao filósofo alemão Kant, e exagera ao conferir valor absoluto à liberdade humana, quase que desconsiderando que, numa criatura limitada, como é o ser humano, a liberdade sempre será parcial e relativa.

O modelo pragmatista, por sua vez, baseia-se no princípio do 'custobenefício' e na óptica utilitarista, também bastante difundido entre nossos contemporâneos. Trata-se de uma faceta do materialismo, que nos considera a todos simples amontoados de proteínas reunidas ao acaso e destinadas a desagregar-se cedo ou tarde, cifrando nosso valor pela nossa utilidade social.

Por fim, o modelo sociobiológico ou naturalístico, que o jornalista inglês Paul Johnson deu recentemente o nome de 'fundamentalismo

\footnotetext{
7 Essa corrente bioética denomina-se Principialismo, inaugurada em 1978 à partir da promulgação do Relatório Belmont nos Estados Unidos.

8 BELLINO (1997) refere-se ao modelo bioético denominado Personalismo Ontologicamente Fundado, proposto por ELIO SGRECCIA (1996).
} 
REVISÃO DE LITERATURA

darwinista', afirma que tudo evolui em função do 'bem do gene'. De uma maneira muito significativa, uma das obras de referência desta corrente se

intitula cinicamente 'O gene egoísta'. Em conseqüência, afirma este modelo que a moral deve igualmente subordinar-se ao avanço inexorável do progresso biológico, social e científico.

Para Ramos ${ }^{9}$ (2005) esses três modelos propostos por Espinosa (1998), podem ser considerados como três correntes de pensamento bioético: o individualismo, o hedonismo e o utilitarismo considerados pelo autor como verdadeiras ideologias que exercem forte influência também na reflexão ética (informação verbal).

O individualismo caracteriza-se, de forma bem sucinta, por resumir tudo na reivindicação da liberdade. Já o hedonismo, a busca da supressão da dor e a extensão do prazer se constituiriam no sentido do agir moral - aqui se confunde prazer físico, representado pela ausência de fenômenos dolorosos, com felicidade. O utilitarismo, por sua vez, faz uma correlação lógica entre custos e benefícios, e o sentido do agir moral passa a ser o que gera lucro, ou, pelo menos, não dá um grande prejuízo ou minimiza seus efeitos. Segundo o autor, essas três posturas - individualismo, hedonismo e utilitarismo -, isoladamente ou em conjunção, favorecem um clima cultural onde não se reconhece nada como definitivo. É o que podem chamar relativismo: a última medida passa a ser o próprio eu e suas vontades.

Pegoraro (2001) reconhece a existência de um modelo de bioética ao qual nomeia antropocósmico. Segundo esse modelo, há o reconhecimento da especificidade única do salto evolutivo do homem que, como produto mais elevado da evolução, tem um grau de dignidade próprio que não se confunde com a especificidade dos outros seres. Esta situação ímpar não confere ao homem poderes indiscriminados e sem limites sobre outras criaturas. Pelo

\footnotetext{
${ }^{9}$ Dor e qualidade de vida, à luz da bioética de modelo personalista. Aula proferida no curso Reflexões em torno da dor, na Faculdade de Medicina de Ribeirão Preto, em 29/11/05.
} 
contrário, cabe-lhe a responsabilidade maior de conduzir eticamente todo o processo evolutivo da natureza, agora consciente nele e por ele.

Desta dignidade faz parte também o embrião humano que reúne todos os componentes genéticos do futuro ser humano adulto, pois dos componentes genéticos humanos não pode nascer, por exemplo, uma plantinha ou um gatinho. Numa palavra, o embrião humano não pode ser reduzido a nenhum outro. É claro que esta posição se distancia da posição dualista (teológica e filosófica), que faz do embrião humano um ser de origem sobrenatural, e da posição utilitarista, que faz do embrião humano um mero material biológico.

O autor ainda ressalta que a convergência antropocósmica reúne duas vertentes de saber; a científica e a simbólica. Os cientistas têm consciência que não podem dizer tudo sobre o ser humano; e as teorias simbólicas (filosóficas, psicológicas ou teológicas) não conseguem explicar o mistério humano apenas com princípio metafísicos. É preciso que todas as formas de saber entrem em diálogo, mútuo esclarecimento e informação.

O Modelo Personalista de Bioética, por sua vez, segundo o autor que propôs e melhor trabalhou o tema, Sgreccia (1996), coloca-nos uma 'antropologia de referência' que busca entender o homem na sua essência, em sua natureza, em sua verdade, em sua totalidade e em sua unidade.

O ponto de partida para o estudo da bioética sob a óptica personalista é reconhecer a pessoa, sua identidade e sua essência, pois só reconhecendo-a podemos, então, saber como respeitá-la. Esse reconhecimento, por sua vez, tem como desdobramento o respeito à dignidade da pessoa humana, e é este o enfoque a ser conferido à assistência domiciliária odontológica no decorrer do presente trabalho. 
3 O PROGRAMA DE ATENDIMENTO DOMICILIÁRIO 


\section{O PROGRAMA DE ATENDIMENTO DOMICILIÁRIO}

Já fora mencionado que ao longo da evolução histórica e em face do progresso da sociedade brasileira as formas de organização da produção e a distribuição espacial da população foram sendo altamente modificadas como resultado da diminuição das taxas de fecundidade e de mortalidade, da redução do tamanho das famílias em geral e dos processos de industrialização e urbanização crescentes no país, essencialmente após a década de 1950.

Também conforme já mencionado, o sistema de saúde brasileiro atual vem se caracterizando, cada vez mais, pelo aumento da população idosa e, consequentemente, da ocorrência de doenças crônico-degenerativas para as quais as unidades de tratamento médico-hospitalares não estão preparadas para lidar no que tange ao aumento de internações de longo e médio prazo, e aos custos que isso gera, o justificando em parte o incentivo que é dado à rotatividade dos leitos hospitalares com a valorização do atendimento domiciliário.

Conforme bem observado por Shirota e Araújo (2001), a população brasileira em massa necessita de atendimento odontológico, entretanto esse serviço parece estar apenas disponível à população economicamente ativa e com melhores condições de vida.

Segundo Chaves (1986), à medida em que a odontologia cresceu em complexidade, em paralelo com a melhoria dos níveis de vida das populações e o aumento da demanda por serviços dentários, diminuiu proporcionalmente o tamanho da população que podia ser atendida de modo adequado por um dentista.

Nesse sentido cumpre mencionar que, no que diz respeito aos serviços públicos de saúde no Brasil, corporificados no SUS, existe uma proposta de modelo assistencial que vem sendo desenvolvida, chamada Programa Saúde da Família (PSF), introduzido pelo Ministério da Saúde em 1994, que vem trazendo 
recompensadores resultados e que procura ampliar o espaço de saúde bucal na atenção básica em saúde.

Dentro desse contexto, a modalidade de atendimento domiciliário odontológico atende às necessidades de se promover tratamento odontológico para pacientes impossibilitados de acessar um consultório convencional ou 0 hospital, sendo que qualquer esforço no sentido de eliminar barreiras ou diminuí-las a fim de que se promova um atendimento odontológico adequado será sempre muito bem visto para a profissão do Cirurgião-Dentista.

\subsection{Considerações técnicas e legais}

O primeiro diploma legal a disciplinar as modalidades de atendimento domiciliário exercidas no país foi a Lei o 8.080, de 19 de setembro de 1990 , recentemente alterada pela Lei $\mathrm{n}^{0} \mathbf{1 0 . 4 2 4}$, de 15 de abril de 2002, que houve por bem acrescentar o capítulo e o artigo que dispõem sobre as condições para a promoção, proteção e recuperação da saúde, a organização e o funcionamento de serviços correspondentes além de outras providências, regulamentando a assistência domiciliária no Sistema Único de Saúde.

De acordo com a Lei no 10.424/2002, todas as modalidades de cuidado realizado no domicílio integram a assistência domiciliária, conceito, por sua vez, definido pela ANVISA (2003) como sendo um termo genérico que representa diversas modalidades de atenção à saúde desenvolvidas no domicílio, entre elas o Atendimento e a Internação Domiciliária.

Tem-se, em outras palavras, que o atendimento domiciliário é definido como um conjunto de atividades de caráter ambulatorial, programadas e continuadas por meio de ações preventivas e/ou assistenciais com a participação de uma equipe multiprofissional (ANVISA, 2003), diferentemente do que se 
entende por internação domiciliária, que consiste, por sua vez, em um conjunto de atividades caracterizadas pela atenção em tempo integral para pacientes com quadros clínicos mais complexos e com necessidade de tecnologia especializada de recursos humanos, equipamentos, materiais, medicamentos, atendimento de urgência/emergência e transporte (ANVISA, 2003).

A atividade odontológica voltada ao atendimento domiciliário objetiva, em linhas gerais, cuidar de indivíduos que não poderiam, de outra forma, receber tratamentos adequados em odontologia, abrangendo, principalmente, idosos e pessoas consideradas "pacientes com necessidades especiais" ${ }^{10}$.

Como exemplos de atividades tidas como genuíno atendimento domiciliário, no Estado de São Paulo, podemos citar o Serviço de Assistência Domiciliária ao Idoso (SADI) do Centro de Referência à Saúde do Idoso do Município de Guarulhos; o Núcleo de Assistência Domiciliar Interdisciplinar (NADI) do Hospital das Clínicas da Faculdade de Medicina da Universidade de São Paulo (HC-FMUSP), e o Programa de Assistência Domiciliária do Hospital Universitário da Universidade de São Paulo (PAD-HU/USP), implantado em 02 de maio de 2000, e que demanda ao paciente o acompanhamento periódico de uma equipe multidisciplinar, altamente qualificada, após alta hospitalar ou problemas de saúde que dificultem seu acesso ao hospital.

De acordo com o levantamento estatístico realizado em 1996 no Hospital do Servidor Público Estadual de São Paulo, no Município de Guarulhos, onde funciona o SADI, 833 pacientes foram acompanhados pela assistência domiciliária, sendo que a transferência dos pacientes crônicos e convalescentes integrados nesse programa promoveu a liberação de leitos hospitalares para os casos que realmente necessitavam de internação, ampliando, assim, a oferta de

\footnotetext{
${ }^{10} \mathrm{O}$ termo 'paciente especial' é extremamente abrangente e subjetivo, e nem sempre um paciente especial está impossibilitado de acessar um consultório convencional. Entretanto, algumas deficiências físicas ou mentais limitam sobremaneira o deslocamento dos indivíduos portadores. Ademais, de acordo com DUALIBI (2001) "a história dos atendimentos odontológicos aos pacientes especiais inicia com a atuação de abnegados profissionais que, que por alguma razão, se sentiram motivados a prestar serviços odontológicos a um grupo de pacientes que encestavam de cuidados especiais".
} 
leitos, diminuindo a média de permanência hospitalar e os custos de internação (MONTEIRO e MONTEIRO, 2000). Nas estatísticas mais recentes, os idosos constituem o grupo etário mais freqüentemente hospitalizado, cerca de três vezes mais que a população mais jovem, sendo aqueles os mais beneficiados pela implementação de programas dessa ordem (HOSPITAL DE CLÍNICAS DE SÃO PAULO, 1995).

O objetivo principal do NADI, por sua vez, é a desospitalização de pacientes cujo tratamento possa ser feito em domicílio, seja reduzindo seu período de internação e/ou a freqüência de novas admissões. Seus objetivos secundários são: garantir ao cliente os recursos terapêuticos e a assistência profissional que teria no hospital; envolver a clínica de origem do paciente na orientação conjunta do processo terapêutico (cooperação profissional); envolver familiares e cuidadores nos cuidados do cliente (cooperação assistencial); educar e instruir o paciente e seus familiares, cuidadores e comunidade orientando-os acerca de noções básicas de saúde e de atitudes adequadas à boa evolução específica de cada caso; criar condições familiares para bem assistir as necessidades físicas, psíquicas e sociais de cliente e cuidadores, incluindo nos casos terminais, as orientações necessárias para que o falecimento possa ocorrer em domicílio, se assim for desejado por todos (JACOB FILHO; CHIBA; ANDRADE, 2000).

A fim de promover semelhantes atividades, a equipe multiprofissional e interdisciplinar que compõe o PAD-HU/USP mantêm médicos, psicólogos, assistentes sociais, enfermeiras, cirurgião-dentista, fonoaudióloga, nutricionista, farmacêutico e terapeuta ocupacional entre outros, contando, ainda, com o apoio administrativo e funcional de secretárias e motoristas.

Ademais, como qualquer equipe voltada ao atendimento domiciliário, tem como principais objetivos: diminuir o tempo de internação do paciente, otimizando a utilização do leito hospitalar; prevenir reinternações; orientar o cuidador e familiares; reinserir o paciente no meio sócio-familiar; melhorar 
a qualidade de vida do paciente e de seus familiares e proporcionar a formação de profissionais de saúde.

Para atingir essas metas, prioriza-se o desenvolvimento das seguintes atividades: assistência domiciliária; encontros com os cuidadores; reuniões com cuidadores; socialização e lazer com cuidadores e pacientes; reunião com família; reuniões da equipe multiprofissional; reuniões científicas; visitas a outras instituições, participação em eventos científicos, com elaboração e apresentação de trabalhos e desenvolvimento de atividades didáticas, como aulas e acompanhamento de estágios das diversas disciplinas em saúde.

\subsection{O exemplo do Programa desenvolvido pelo Hospital Universitário da Universidade de São Paulo (PAD-HU/USP)}

Conforme mencionado no item anterior, o PAD-HU/USP é um exemplo de atividade tida como genuíno atendimento domiciliário, no Estado de São Paulo, implantado em 02 de maio de 2000, e que adotou como modalidade de atendimento a Assistência Domiciliária conceituada por Duarte $\mathrm{E}$ DIOGO (2000).

O programa demanda ao paciente o acompanhamento periódico de uma equipe multidisciplinar ${ }^{11}$, altamente qualificada, após alta hospitalar ou problemas de saúde que dificultem seu acesso ao hospital.

A equipe multiprofissional e interdisciplinar que compõe o PADHU/USP mantêm médicos, psicólogos, assistentes sociais, enfermeiras, cirurgião-dentista, fonoaudióloga, nutricionista, farmacêutico e terapeuta ocupacional entre outros, contando, ainda, com o apoio administrativo e funcional de secretárias e motoristas.

\footnotetext{
${ }^{11}$ A multidisciplinariedade, ou multiprofissionalidade, caracteriza-se pela concorrência/colaboração entre os cientistas das diversas áreas do conhecimento humano quando do estudo de um objeto que é comum a todos. Nos grupos ditos multidisciplinares, cada cientista torna-se responsável pela análise do mesmo e único objeto estudado, de acordo com os critérios inerentes à sua área de atuação, resguardando-se a especialidade profissional de cada membro da equipe e desvinculando-se qualquer conclusão de um único enfoque dado ao tema.
} 
Atualmente é, também, campo de estágio de alunos dos Cursos de Graduação de Medicina, Odontologia, Fisioterapia, Enfermagem, Terapia Ocupacional, Fonoaudiologia, Psicologia e de alunos da Escola de TécnicoAuxiliar do HU-USP.

O PAD-HU/USP tem como objetivos diminuir o tempo de internação do paciente, otimizando a utilização do leito hospitalar; prevenir reinternações; orientar o cuidador e familiares; reinserir o paciente no meio sócio familiar; melhorar a qualidade de vida do paciente e de seus familiares e proporcionar a formação de profissionais de saúde.

Os critérios de elegibilidade para ingresso no Programa são: o paciente deve ser usuário matriculado no HU-USP e pertencer a comunidade USP e/ou comunidade Butantã ou matriculado nos PSFs das UBSs do Jardim Boa Vista, Vila Dalva, São Jorge ou do Centro de Saúde Escola Butantã; ter indicação e pedido da equipe que assiste o paciente; deve reunir condições clínicas para ser atendido no domicílio; ter cuidador domiciliar eleito pela família e ser residente na área de abrangência do HU/USP, ou seja, bairros pertencentes à subprefeitura do Butantã (Figura 3.1).

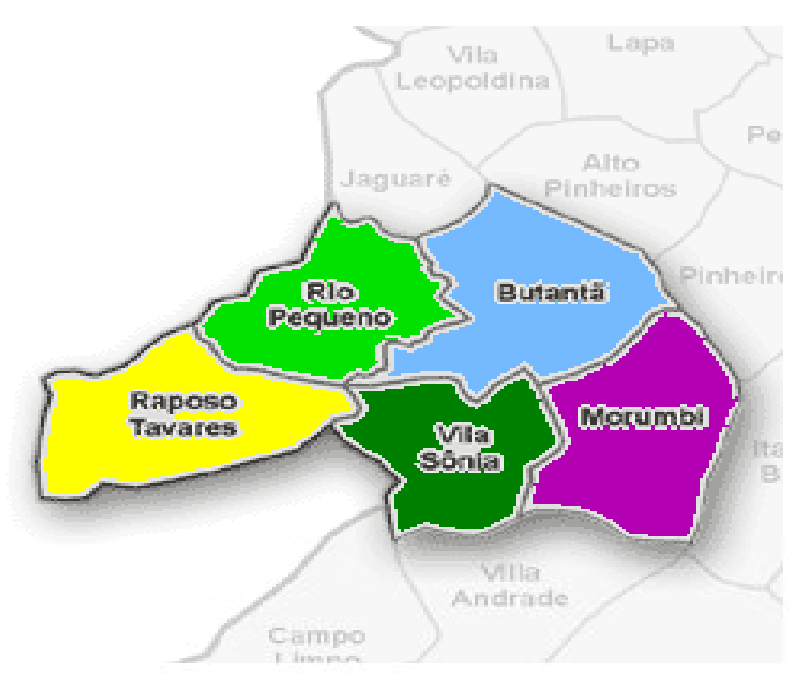

Figura 3.1 - área de abrangência do PAD/HU - USP 
O PROGRAMA DE ATENDIMENTO DOMICILIÁRIO

O processo de inclusão de um paciente no PAD-HU/USP tem início com uma solicitação por escrito da equipe das diversas Unidades de Internação, da Emergência, do Ambulatório do HU/USP, responsáveis pelo paciente ou ainda das equipes de PSFs ou PACs (Programa de agentes comunitários) da subprefeitura do Butantã. A equipe do PAD realiza então uma visita ao leito e faz contato com a equipe solicitante (quando o paciente está internado), consulta o prontuário, discute o caso e programa a visita domiciliária, conforme fluxograma anexo (Anexo A)

Atendidos esses critérios, o paciente e a família recebem a visita da equipe no domicílio, onde são avaliadas a área física da residência, as condições sociais e econômicas da família e definida a periodicidade das visitas que são realizadas de segunda a sexta-feira.

Às quartas-feiras, após a realização das atividades de visitas, a equipe realiza a discussão de casos novos, de casos em acompanhamento, avalia pedidos de inclusão, planeja a assistência e elabora o cronograma semanal de visitas de acordo com o índice de classificação dos pacientes. Cada profissional programa a sua assistência conforme as necessidades de cada paciente. O Cirurgião-Dentista, por sua vez, programa a periodicidade das visitas de acordo com suas especificidades. Promovem, ainda, a discussão de temas de interesse e elaboram documentos e trabalhos relacionados ao programa.

A maioria dos pacientes atendidos pelo PAD (adulto)-HU/USP é do sexo feminino $(57,8 \%)$, com idade entre 70 e 89 anos $(68,9 \%)$, mas que pode atingir de 90 a 100 anos (8,8\%), com diagnósticos principais de acidente vascular cerebral e demências, casados $(60 \%)$, com ensino fundamental incompleto $(31,2 \%)$, analfabetos $(13,3 \%)$, ensino fundamental completo $(8,89 \%)$, ensino superior $(11,11 \%)$, aposentados $(31,2 \%)$, procedentes da comunidade USP (49\%) e da comunidade Butantã (51\%). Quanto ao grau de dependência para a realização das atividades da vida diária foi constatado que em sua maioria apresentam maior dependência no que diz respeito ao controle de esfíncteres 
(incontinência), à habilidade para andar (atividade) e ao controle dos movimentos do corpo (mobilidade), sendo em sua maioria acamados (YAmAmoto; Sportello; Oliveira, 2002). São, em sua maioria, idosos, aposentados com poucos recursos, portadores de doenças crônicas, o que compromete sua autonomia para a realização das atividades básicas da vida diária, especialmente locomoção e mobilização, necessitando de suporte familiar.

Os pacientes são classificados quanto a sua incapacidade funcional através da Escala da Cruz Vermelha Espanhola (Anexo B) e Escala de Braden (Anexo C)

Sportello, Okano e Follador (2001) constataram que a maioria dos cuidadores dos pacientes do PAD-HU/USP é do sexo feminino (90,9\%); na faixa etária de 40 a 59 anos (54,6\%), familiar (70\%), leigo (75,7\%) e com nível de escolaridade variando do ensino fundamental incompleto até o médio completo $(81,9 \%)$.

Ressalte-se, ainda, que a existência cada vez maior de pacientes crônicos pediátricos gerou a necessidade de um Atendimento Domiciliário Pediátrico (PED), agilizando as desospitalizações destes doentes, minimizando as reinternações neste grupo e permitindo a reinserção destes no convívio familiar. O início do PED, em junho de 2002, praticamente coincidiu com o início das atividades do Programa de Oxigenoterapia Domiciliar (POD), em agosto de 2002, o que colaborou para uma boa implantação do PED, já que alguns destes pacientes eram dependentes da oxigenoterapia. São prérequisitos para admissão no PAD pediátrico ser morador da região atendida pelo Programa de Assistência Domiciliária (PAD-HU) e preencher os critérios de inclusão do PAD-HU, ter critérios indicativos de doença crônica em que exista a impossibilidade de seguimento ambulatorial (Ex.: oxigenoterapia contínua) e ter condições sociais e de habitação mínimas satisfatórias para manutenção do tratamento no domicílio.

Além de todas as atividades mencionadas, O PAD mantém um programa de empréstimo de equipamentos para o preparo do domicílio para a 
O PROGRAMA DE ATENDIMENTO DOMICILIÁRIO

assistência domiciliária. Esses equipamentos incluem cadeiras higiênicas, de rodas, camas hospitalares, aspiradores, inaladores, andadores, muletas e bengalas, além de receber doações de equipamentos e materiais de consumo de instituições e dos próprios familiares, que repassam aos outros pacientes.

Ademais, desde setembro de 2003, o grupo de voluntários do HU, coordenados pelo Serviço Social, exerce atividades no PAD. Esses voluntários fazem parte da AVHUSP (Ação Voluntária do HU/USP) e dentre suas funções destacam-se: atividades manuais de pinturas em quadros com os pacientes e cuidadores, apoio emocional, apresentação musical, com a utilização de instrumentos nos domicílios, entre outros (SPORTELLO, 2003).

Atualmente, no HU-USP, as ações de humanização são desenvolvidas por iniciativa dos diversos setores do hospital, contando com a participação da equipe multiprofissional e apoio da Superintendência, tendo como objetivos:

i. Empenhar esforços para sistematizar, convergir e divulgar as ações de humanização;

ii. Promover a conscientização e aderências às propostas de humanização do ambiente hospitalar entre o usuário interno, externo e instituição;

Estabelecer a integração das ações de humanização do atendimento hospitalar

iii. Promover a humanização do trabalho realizado pelo usuário interno; iv. Assegurar a continuidade das ações humanizadoras.

Esses recursos têm sido benéficos para um atendimento mais humano, revelando aspectos obscuros no contexto profissional, aumentando o nível de satisfação dos usuários, minimizando fatores estressores causados pela hospitalização, propiciando, ainda, um ambiente de trabalho agradável e prazeroso, que possibilita maior satisfação da equipe e conseqüentemente melhoria na qualidade assistencial. 


\subsection{A atuação do Cirurgião-Dentista na equipe multiprofissional do PAD-HU/USP}

Evidenciadas as características fundamentais do PAD-HU/USP, cumpre adentrar à análise da importância das atividades exercidas pelo Cirurgião-Dentista no Programa.

A experiência demonstra que a ausência do Cirurgião-Dentista acabava por permitir que outros profissionais da saúde, e mesmo os cuidadores, tomassem iniciativas incipientes quanto à higiene, presença de feridas bucais causadas por próteses mal adaptadas, presença de focos infecciosos que agravavam o estado de saúde bucal e sistêmico, acarretando, ainda, desnutrição dos pacientes, agravando sensivelmente seu quadro clínico sistêmico.

Segundo Leme (2000), os conhecimentos e habilidades específicos de diversos profissionais em saúde, compondo uma equipe multidisciplinar, parece ser a melhor alternativa para a estruturação da atenção à saúde de idosos (e pacientes com dificuldades sistêmicas em geral).

Há que se ter em mente, entretanto, que a interdisciplinaridade não se resume na somatória de disciplinas, mas sim na intersecção entre elas, de modo a garantir uma complementaridade entre todas as áreas (LEMOS, 2001).

O Cirurgião-Dentista é, portanto, de fundamental importância para o oferecimento de um programa assistencial integral e qualificado, capaz de abranger o paciente e seus cuidadores, no âmbito familiar e/ou comunitário, em todas as suas necessidades de saúde.

Brunetti (2002) salienta que casos de pacientes com necessidades tão diversas não são comuns na prática diária de dentistas: "a troca de informações contínua permitirá [dessa forma] que o dentista identifique outras áreas que podem estar levando as conseqüências na cavidade bucal e como seus efeitos 
podem ser atenuados ou eliminados - candidíase, queilite angular, condições bucais da diabete são alguns destes - visando ao conforto geral do paciente".

Nesse contexto, as informações contidas em um prontuário multidisciplinar serão de extrema importância, especialmente nos casos de pacientes que necessitam de exodontias e apresentam doenças sistêmicas crônicas ou, ainda, permanecem em tratamento por lesões ou doenças específicas, que necessitem de compensação para a realização do ato cirúrgico, ou medicações profiláticas (Anexos D, E, F, G, H e I).

Frise-se que para que esses atendimentos sejam realizados de modo apropriado e satisfatório, devem ser consideradas as necessidades específicas dos pacientes, os recursos disponíveis em relação aos equipamentos, a legislação que regulamenta os variados tipos de procedimento e, ainda, a ética que os envolve.

Nesse ponto, é imperioso reconhecer que o Cirurgião-Dentista é, antes de ser um profissional da saúde, um cidadão cuidando de outros cidadãos, com a responsabilidade de promover também o conforto psíquico, social e espiritual, além do conforto físico inerente à sua atividade.

Isolando, agora, as atividades exercidas pelo Cirurgião-Dentista inserido na equipe multidisciplinar de atendimento domiciliário, ou seja, no que tange à assistência individual do Cirurgião-Dentista, temos que este profissional compromete-se com 0 dever de implementar 0 atendimento odontológico utilizando-se de novos materiais e procedimentos realizáveis em domicílio, criar programas de higiene e prevenção à saúde bucal, estimulando e promovendo o bem estar e incentivando práticas que auxiliem toda a família, realizar condutas específicas clínico-cirúrgicas, passíveis de serem realizadas em domicílio, controlar as orientações terapêuticas sobre higiene, dieta e fisioterapia bucal, encaminhar e adequar o paciente a procedimentos realizáveis em domicílio.

Pode-se dizer, ainda, que suas atividades extrapolam a esfera domiciliar do paciente, na medida em que também é responsável pelas 
atividades de ensino que consistem, em suma, no acompanhamento e orientação de estágios dos alunos da disciplina de Odontologia Hospitalar e curso de extensão em Assistência Domiciliária.

Participa, ainda, do desenvolvimento acadêmico-científico com apresentação de trabalhos em congressos e eventos sobre Assistência Domiciliária, participa, ainda, rotineiramente, no apoio administrativo por meio da elaboração de manual administrativo, manual para cuidador e elaboração de manual odontológico para atendimento domiciliário.

Assim, os objetivos específicos do Cirurgião-Dentista consistem tanto na terapêutica clínica semiológica (anamnese, diagnóstico, prognóstico e terapêutica referente a patologias bucais), quanto na terapêutica clínicocirúrgica e preventiva (programas de higiene e prevenção de saúde bucal, acompanhamento preventivo, profilático e curativo, conduta terapêutica clínicocirúrgica, prescrição de medicamentos quando necessário), avaliadas pelo profissional durante a visita domiciliária (Anexo D).

A visita domiciliária, por fim, deve ser cuidadosamente realizada, uma vez que o cuidado em domicilio tende a "invadir" a privacidade do paciente, destacando-se a importância da atuação ética e profissional de todos os membros da equipe multidisciplinar dedicada ao atendimento domiciliário e ao "homecare".

\subsection{O relacionamento profissional-paciente: em busca de relações mais humanas}

Segundo Sgreccia (1996), humanização consiste em reconhecer no outro (pessoa humana) a dignidade que lhe é inerente.

Humanização é, também, o processo que confirma no homem aqueles traços que reputamos essenciais, como o exercício da reflexão, a 
O PROGRAMA DE ATENDIMENTO DOMICILIÁRIO

aquisição do saber, a boa disposição para com o próximo, o afinamento das emoções, a capacidade de penetrar nos problemas da vida, o senso da beleza, a percepção da complexidade do mundo e dos seres, o cultivo do humor.

As várias dimensões formadoras do homem e a importância desse reconhecimento por parte dos profissionais da área da saúde, possibilitam um atendimento mais humano e de melhor qualidade. Dentro deste contexto, a importância da busca por um cuidar humanizado como desafio dentro das instituições de saúde realça a importância e a necessidade da dimensão humana no cuidado do sofrimento e da dor.

A reflexão sobre as dificuldades encontradas no cotidiano dos profissionais e pacientes, ambos fragilizados com a perspectiva da vida, doença, morte com respeito e dignidade, é o motivo deste capítulo. Assim, a assistência domiciliária como elemento humanizador, é um item importante a ser considerado no decorrer da abordagem sobre HUMANIZAÇÃO.

Em linhas gerais, um cuidar humanizado baseia-se no forte e bom vínculo profissional/paciente, ou seja, é acolher a fragilidade do próximo nos momentos de angústia. Dessa forma, a presença do profissional se solidifica com o desenvolvimento da habilidade humana. É de suma importância não esquecer que, para haver vínculo entre pessoas, principalmente entre profissional e paciente, é imprescindível que haja reciprocidade, igualdade de oportunidades e ausência de preconceitos.

Ao longo de sua história, o homem pôde perceber que representa o vértice da vida no universo, sendo a forma mais rica, mais autônoma e mais ativa de vida, diferenciando-se não só pela morfologia ou número cromossômico, mas pela capacidade de inteligência e raciocínio, sociabilidade e política, e com livre arbítrio de optar.

Assim, o que diferencia o ser humano da natureza ou dos animais é que seu corpo biológico é capturado desde o início numa rede de imagens e palavras, apresentadas primeiras pela mãe, depois pelos familiares e em seguida pelo 
social. É esse "banho" de imagem e de linguagem que vai moldando o desenvolvimento do corpo biológico, transformando-o num ser humano, com estilo de vida e modo singulares (CHAUÍ, 1997).

O fato de sermos dotados de linguagem torna possível a construção de redes de significados, que compartilhados em maior ou menor grau com nossos semelhantes, nos propiciam uma identidade cultural.

A existência humana apresenta-se, ainda, como corporeidade e espiritualidade e se realiza dentro de um contexto social, apresentando uma singularidade única por meio da consciência e da liberdade. O homem é capaz de transformar imagens em obras de arte, palavras em poesia, literatura e sons em fala e música, ignorância em saber e ciência. É capaz de produzir cultura e, a partir dela, intervir e modificar a natureza, permitindo um relacionamento com o mundo.

Através da experiência humana, atribuímos significados a nossa existência, que sendo compartilhados, aprofundam 0 conhecimento, transformando a realidade de cada ser humano.

E toda essa capacidade de questionamento, essa curiosidade intelectiva são tão típicas experiências do ser humano como terão seu sentido potencializado a partir do reconhecimento da realidade humana como corpo/espírito, e é o que nos possibilita a evolução e o desenvolvimento em todas as áreas do conhecimento. Porém, não podemos falar em humanização sem levarmos em conta a profunda crise de humanismo que abrange toda nossa sociedade, onde valores como a fraternidade, compaixão, tolerância e a solidariedade estão sendo freqüentemente descartados.

Há, na atualidade, uma verdadeira inversão de valores fundamentais, em que a vida acaba sendo depreciada por posturas individualistas, não se

reconhecendo que liberdade e responsabilidade caminham juntas (INDIVIDUALISMO ${ }^{12}$ ), ignorando-se o fato de que todo ato livre gera

\footnotetext{
${ }^{12}$ Trata-se de um conceito político-moral e social que exprime a formação e liberdade do indivíduo frente a um grupo especialmente à sociedade e ao Estado. Usualmente toma-se por base a liberdade no que
} 
implicações com as quais devemos conviver. Somos, portanto, os responsáveis por nossas escolhas.

A busca pelo prazer $\left(\mathrm{HEDONISMO}^{13}\right.$ ) como único referencial nos incapacita de assimilar a dor e sofrimento, que também faz parte da existência humana, e como tal precisa ser reconhecida e trabalhada dentro do contexto social no qual estamos inseridos e interagimos.

Com o propósito de aliviar ou sanar o sofrimento, entendendo a importância de nossa dimensão social, de nossa necessidade de relacionamento com o mundo e de reconhecimento do outro como semelhante.

O consumismo desenfreado (UTILITARISMO ${ }^{14}$ ), a meta da eficiência econômica valoriza o ter e estar em detrimento do ser, porque fragmenta a pessoa e só se empenha em cuidar deste único aspecto, reduzindo tudo a uma relação custo-benefício, onde a dignidade de cada pessoa passa a ser diferente de acordo com seu sucesso econômico.

Essa inversão de valores desumaniza a sociedade como um todo.

Reflete-se nas relações interpessoais dentro das instituições de saúde, acentuando a assimetria de poder e as desigualdades sociais. Sem dúvida, as diferenças econômico-sociais criam uma enorme exclusão social onde os pacientes são colocados em uma posição de inferioridade tal que culmina em seres humanos invisíveis aos olhos de outros seres humanos ${ }^{15}$ (BOSI, 2005).

concerne a propriedade privada e a limitação do poder do Estado. O individualismo em si opõe-se a toda forma de autoridade, ou controle sobre os indivíduos; e coloca-se com antítese do coletivismo. Louis Dumont, antropólogo francês e autor de obras consagradas, estudou profundamente o sistema de castas da índia, teorizando sobre as ideologias da hierarquia e igualdade, e a emergência do individualismo na sociedade moderna. (Liener, 2003).

${ }^{13}$ É uma teoria ou doutrina filosófico-moral que afirma ser o prazer individual ou imediato o supremo bem da vida humana. Surgiu na Grécia na época pós-socrática, e um dos maiores defensores da doutrina foi Aristipo de Cirene, discípulo de Sócrates, também grande estudioso da época. O Hedonismo moderno procura fundamentar-se numa concepção mais ampla de prazer entendida como felicidade para o maior número de pessoas (http://pt.wikipedia.org/wiki/Aristipo_de_Cirene, consultado em 25/05/2006).

${ }^{14}$ Foi provavelmente Hume quem, junto com seus colegas do iluminismo escocês, avançou pela primeira vez a idéia de que a explicação dos princípios morais deverá ser procurada na utilidade que eles tendem a promover. Mas foi seu compatriota Francis Hutcheson que cunhou o slogan utilitarista: "maior felicidade para o maior número". (MILL, 2005).

15 "A humanidade lutou por séculos para acabar com o preconceito contra as mulheres, depois lutou e ainda luta contra preconceitos raciais. Agora, entra no século 21 no 
Devemos, pois, procurar resgatar a identidade do homem em sua totalidade, nas suas diferenças, no pluralismo e na diversidade - TORNÁ-LO VISÍVEL!

A compreensão do ser humano e do significado da vida é uma questão importante para os profissionais da saúde, tais como os valores éticos que devem dirigir nossas ações e imprimir em nossas relações sociais condições que propiciem e valorizem o respeito à vida e à dignidade da pessoa humana.

A pessoa desenvolve a consciência de si mesmo como ser indivisível, possuidor de personalidade e necessidades próprias, com uma vivência diferenciada, de acordo com o contexto sócio-cultural no qual está inserida, o que vai moldando-a por meio das experiências vividas. Essa formação e reconhecimento do seu próprio eu passa necessariamente pela relação com seus semelhantes, e só se tornou possível através da comunicação.

O desenvolvimento das ciências experimentais (cartesianismo) favoreceu o especialismo, reduzindo a atenção para a doença e sua cura, negligenciando, assim, a visão sobre o paciente enquanto uma pessoa, um TODO.

A capacidade de amar e respeitar o próximo, de se doar livremente, de utilizar a inteligência e a vontade dando um sentido à existência é o que nos diferencia dos animais e da natureza, possibilitando-nos ser reconhecidos como seres humanos.

A humanização do cuidar implica, portanto, no conhecimento e reconhecimento das várias dimensões formadoras do ser humano, de sua essência única e, ao mesmo tempo, multifacetada, reconhecendo-o para além de sua dimensão corpórea, situando-o assim num contexto onde se valorizam também as suas dimensões psicológica, social e espiritual (RAMOS, 2005) ${ }^{16}$. 
O PROGRAMA DE ATENDIMENTO DOMICILIÁRIO

Assim, o cuidar humanizado exige dos profissionais da área da saúde a compreensão da dor nas diferentes dimensões em que ela se apresenta nos seus aspectos biológicos, emocionais e culturais, considerando também outros fatores que, assim como a dor física, causam sofrimento.

Ressalte-se, neste ponto, que o desenvolvimento tecnológico reduziu-nos a uma mentalidade onde predomina o conhecimento científico e a eficiência técnica, voltando a atenção do profissional para a doença e sua cura, aumentando a necessidade de especialização.

Ora, são indiscutíveis os benefícios proporcionados pela tecnologia, mas esse mesmo avanço da ciência acabou por nos conduzir a uma despersonalização, reduzindo o doente a uma patologia a ser tratada (ISMAEL, 2002).

O avanço tecnológico e científico, ainda que benéfico e imprescindível, não pode ser dissociado das percepções afetivas, do reconhecimento do outro e do respeito à sua dignidade (MARTINS, 2001).

No trabalho de um profissional, qualquer que seja sua atividade, há uma dependência tanto da qualidade técnica como da qualidade de interação.

Esse tipo de formação profissional, cada vez mais especializado, e as próprias condições de trabalho existentes no mercado, acabam por restringir a disponibilidade do profissional tanto para o contato com o paciente quanto para a busca de formação mais abrangente (ARAÚJO, 2004).

As pessoas passam a ser meros objetos de intervenção técnica sem serem ouvidas em suas angústias, temores e expectativas, ou sequer informadas sobre o que está sendo feito com elas. Ora, não estamos diante de simples corpos ou máquinas, mas de pessoas que precisam ser acolhidas em suas necessidades pessoais e emocionais (MARTINS, 2001).

A doença passou a ser o objeto de estudo, e numa visão reducionista do ser humano, este passa a ser apenas um órgão a ser tratado. Os relacionamentos são afetados e a interação social prejudicada dentro das instituições prestadoras de serviços na área da saúde, fazendo com que as pessoas sintam-se diminuídas, despersonalizadas e isoladas, aumentando 
O PROGRAMA DE ATENDIMENTO DOMICILIÁRIO

consideravelmente a sensação de insegurança e vulnerabilidade inerentes à situação de doença (SGRECCIA, 1996).

Dentro do ambiente hospitalar o profissional deve seguir uma série de normas e rotinas que não devem dificultar uma aproximação e um atendimento mais humanitário.

A humanização do ambiente hospitalar começa, portanto, com o entendimento de saúde como o bem-estar do indivíduo, que deve ser buscado em todas as dimensões: física, mental, social e espiritual. O profissional deve conhecer a realidade do paciente, fazê-lo compreender sua doença e amparálo em sua fragilidade, e mesmo diante de um impedimento de cura, investir no seu bem-estar (RAMOS, 2002).

$\mathrm{Na}$ esfera de atuação da assistência domiciliária, a humanização deve seguir semelhantes (ou até as mesmas) diretrizes da esfera hospitalar sendo que o maior desafio dos profissionais da saúde é desenvolver habilidades técnicas e humanas, na busca de soluções que possam melhorar a grave situação dos pacientes menos favorecidos, proporcionando-Ihes uma vida mais digna (DUARTE; DIOGO, 2000).

Há que se dedicar, nesse ponto, atenção à comunicação utilizada pelos profissionais com seus pacientes.

A comunicação, em linhas gerais, nos permite a interação social, sendo a linguagem falada a forma mais utilizada pelo ser humano. No entanto, a comunicação não verbal é a que mais significado possui do ponto de vista da humanização, mesmo quando a comunicação verbal já não pode ser utilizada.

Pela utilização da linguagem, os pacientes, por exemplo, podem exprimir seus pensamentos e necessidades, possibilitando sua inclusão na dinâmica familiar e social.

Com o avançar da idade ocorrem mudanças degenerativas e fisiológicas no sistema auditivo, e um declínio no processamento auditivo central, comprometendo seriamente o processo de inteligibilidade da fala, além das muitas mudanças no aparelho estomatognático decorrentes do próprio envelhecimento e das doenças que porventura aparecem (DUARTE e DIOGO, 2000). 
E é exatamente na boca que há uma grande repercussão dos sinais e sintomas do envelhecimento e enfermidades. Ocorrem alterações estruturais com maior ou menor impacto na fonação. É exatamente na face, na boca, por onde exprimimos nossos desejos e emoções (JORGE,2003) e por onde, com certeza, sem importar o grau de deformidade nessa região, nos sentimos inferiorizados, excluídos, isolados. (ALVES, 2006).

Componentes raciais, hereditários, alimentares, ambientais e emocionais podem influenciar na presença destas alterações.

Dessa forma, a comunicação verbal é prejudicada, o que limita o desempenho de atividades da vida diária, agravando ainda mais as condições de autonomia e independência do idoso. Isto pode fazer com que o idoso (e pacientes que apresentem essa limitação comunicativa em geral) se afaste de situações de comunicação, prejudicando seu contato social e levando-o a situações de isolamento.

Precisamos ouvi-los cuidadosamente, olhando-o nos olhos, estando atentos às suas expressões e linguagens corporais (gestos simbólicos) para que a comunicação possa ser estabelecida e para que o vínculo seja criado. Em outras palavras, precisamos ouvir mais e falar menos.

Trata-se, ainda, de reconhecer a pessoa em sua totalidade, com seus componentes físicos, mentais, sociais e espirituais, e é exatamente neste ponto que entra a importância do enfoque conferido pela Bioética de Modelo Personalista a todo e qualquer procedimento ligado à promoção da saúde e, especificamente, ao atendimento domiciliário odontológico objeto da presente dissertação. Vejamos, então, o que preceitua o Modelo Personalista. 
4 O ENFOQUE CONFERIDO PELA BIOÉTICA DE MODELO PERSONALISTA AO ATENDIMENTO DOMICILIÁRIO 


\section{O ENFOQUE CONFERIDO PELA BIOÉTICA DE MODELO PERSONALISTA AO ATENDIMENTO DOMICILIÁRIO}

Há vinte anos realizou-se em Alma-Ata, na antiga União Soviética, convocada pela Organização Mundial da Saúde, uma reunião das mais altas autoridades de saúde, que teve grande influência na evolução dos sistemas de saúde nestas últimas décadas. A Declaração de Alma-Ata e seu lema "Saúde para todos no ano 2000" fixaram uma meta ideal que, longe de ter sido atingida, serviu de guia para planos e ações de saúde nestas duas décadas. Nas revisões recentemente feitas sobre o progresso realizado não se estabeleceu um novo prazo, mas manteve-se o lema "saúde para todos". Esse lema reflete o que todos aspiramos, mas não inclui indicação sobre o caminho a atingi-lo. Deixa implícito o que melhor seria deixar explícito (CHAVES, 2001).

Para progredir na direção dos ideais da Declaração de Alma-Ata, necessitamos de uma Ética prática, que se manifeste não só no que dizemos, mas no que fazemos, no nosso comportamento cotidiano. O comportamento ético é o comportamento consensualmente esperado do indivíduo bom e se adquire de uma maneira muito semelhante a outros tipos de comportamento ligados à cidadania. Ética e cidadania são conceitos inter-relacionados, uma vez que o comportamento ético caracteriza o cidadão no sentido pleno da palavra (CHAVES, 2001).

Num país grande como o Brasil, devemos considerar aspectos éticos em vários níveis. Vão do macro ao meso (estados) e ao micro (municípios), e até mesmo submeto, representado por pequenas comunidades, bairros, chegando até à unidade social menor, que é a família. Devemos considerar a saúde em seu caráter multidimensional, e com múltiplos atores em diferentes arenas ou cenários: políticos, autoridades, chefias, profissionais, técnicos e pessoal auxiliar dos serviços públicos de saúde; profissionais liberais e suas corporações; clientelas, 
usuários e, até mesmo, os excluídos do sistema; organizações e lideranças comunitárias nos diversos níveis. Em cada nível e para cada tipo de atores existem comportamentos éticos, que deles esperamos, relacionados com a Saúde (CHAVES, 2001).

Quando se pensa em desafios éticos ligados ao atendimento domiciliário odontológico duas das primeiras indagações que nos vêm à mente são: Afinal, qual é o papel do Cirurgião-Dentista e onde estão os limites de sua atuação profissional, se é que eles existem?

Para Ferreira (2001) não existem respostas certas ou erradas em termos de atendimento domiciliário: trata-se de exercício de criatividade. Segundo o autor, o programa de atendimento domiciliário, ou, nos termos por ele mesmo utilizados, o programa de saúde da família (PSF) visa resolver problemas de uma única e determinada comunidade, limitada quantitativamente, com endereço fixo e conhecido. Portanto, o profissional tem obrigatoriamente que se co-responsabilizar pela saúde daquelas pessoas.

Ademais, torna-se inviável a existência de um bom programa de atendimento domiciliário se as pessoas envolvidas não estiverem realmente compromissadas com ele. A formação do profissional da saúde está, em geral, comprometida com a saúde do corpo biológico, e não com o indivíduo (corpo, mente e espírito) ou uma coletividade (FERREIRA, 2001).

Outro aspecto que merece ser considerado diz respeito ao fato de que os pacientes, até pouco tempo atrás, eram tratados basicamente em hospitais e, agora, são transferidos o mais rapidamente possível para seus domicílios, onde continuarão seus tratamento, com programas de reabilitação, de recuperação, ou de cuidados paliativos.

É natural, portanto, que com o passar do tempo surjam situações conflituosas com os diversos atores envolvidos: o paciente, a família, os cuidadores, o provedor e o gestor de saúde, envolvendo processos decisórios difíceis. Estas situações de tensão e de conflito emergem dentro de um contexto 
OS DESAFIOS DA BIOÉTICA APLICADOS AO ATENDIMENTO DOMICILIÁRIO ODONTOLÓGICO

maior onde alguns aspectos devem ser levados em consideração: (1) há uma crescente tendência dos administradores hospitalares em otimizar as internações e reinternações, pressionados pelos altos custos, com uma maior racionalização do tempo de permanência do paciente no hospital, maior rotatividade dos leitos, diminuição dos custos hospitalares e, nesse sentido, para o gestor, a assistência domiciliária apresenta-se como sendo uma opção importante; (2) há um modelo de formação do profissional da saúde centrado no hospital, com uma gama de recursos à sua disposição, sendo este o local onde ele tende a se sentir mais familiarizado e mais seguro para atuar; (3) existe uma concepção amplamente difundida na comunidade de ser o hospital lugar de excelência para diagnóstico e tratamento; (4) o domicílio é um local onde o poder estabelecido pertence ao paciente ou aos membros daquela família, não sendo, portanto, território natural de atuação do profissional de saúde; (5) há uma população que vivem em realidade geográfica e social muitas vezes desfavorável, em áreas de difícil acesso e com domicílios em precárias condições, o que pode trazer como conseqüência a exclusão de pacientes que poderiam se beneficiar com o atendimento domiciliário; (6) a mulher, que costuma ser um dos atores fundamentais no atendimento domiciliários, representa, na atualidade, importantes esteio financeiro familiar, o que pode comprometer sua atividade de cuidadora podendo vir até a interferir no seu emprego. Pode-se perceber, portanto, que o campo do atendimento domiciliário, onde interagem seus diferentes atores, carrega conflitos de natureza moral e ética, que apresentaremos a seguir (FLORIANI; SCHRAMM, 2004).

No que tange à questão de otimização dos leitos hospitalares, temos que o processo decisório inerente ao gestor de saúde pode ser descrito como um cenário de escassez de recursos, pois tende a concentrar problemas e decisões (gestão tradicional)pautadas por indicadores econômicos (muitas vezes desumanizados), a fim de atuar de forma 'moralmente' legítima, com preocupações em relação aos produtos e resultados finais de organizações de 
OS DESAFIOS DA BIOÉTICA APLICADOS AO ATENDIMENTO DOMICILIÁRIO ODONTOLÓGICO

sua responsabilidade, isto é, aceitável por qualquer agente social razoável e imparcial como resultado da cobrança e do controle social.

A relação existente entre o paciente e seu cuidador, por sua vez, pode se desgastar ao longo do tempo em face da árdua e desgastante tarefa de cuidar. Essa relação, em se tratando de pacientes altamente dependentes para as atividades da vida diária, é bastante complexa e, dependendo o perfil psicológico de ambos, pode tornar-se difícil principalmente no que tange ao exercício da autonomia do paciente que, apesar de dependente e frágil, muitas vezes tem expectativas de exercitá-la tão plenamente quanto em seu passado (NERI, 2000). Surge, ainda, a seguinte questão: até que ponto as ações 'paternalistas', freqüentemente presentes nas ações dos cuidadores, desempenham papel realmente terapêutico? E, por outro lado, quem arcará com os potenciais danos físicos, emocionais, sociais e existenciais do cuidador?

Um outro dilema colocado por Collopy, Dubler e Zuckerman (1990), relaciona-se ao fato de que os pacientes estariam sendo deslocados de modo mais rápido e mais doentes para o domicílio - quicker and sicker - devido aos custos das internações hospitalares.

Arras e Dubler (1994) descrevem situações de tensão e conflitos vivenciadas pelo paciente e sua família em relação ao tempo de permanência hospitalar, bem como dificuldades destes em compreenderem o significado e o valor do atendimento domiciliário, oferecido como alternativa viável e segura. Além disso, os profissionais da saúde formados com enfoque intervencionista podem trazer problemas no domicílio, agindo por ansiedade e por sentirem a necessidade de terem de fazer alguma coisa, podendo gerar um ambiente de desconfiança e tensão.

Há, ainda, famílias e pacientes que impõem condições ao provedor do atendimento domiciliário com respeito ao perfil racial e de classe do cuidador que passará a conviver em seus domicílios, com potenciais conflitos de natureza discriminatória (TOPINKOVÁ, 1995). 
Ademais, será que é legítimo, do ponto de vista moral, que sejam executadas estratégias de convencimento junto ao usuário, movidas por objetivos que podem estar vinculados, única e exclusivamente, à redução de custos? E uma vez implantado o atendimento domiciliário do tipo internação domiciliar, como ficará o acesso a ele pela população mais desfavorecida, muitas vezes com domicílios sem as mínimas condições para sua instalação? A quem, de fato, se destina o atendimento domiciliário e a quem ele deveria, legitimamente, se destinar? De que modo e quanto a experiência de um domicílio submetido às visitas constantes de uma equipe multiprofissional irá afetar as pessoas que nele vivem? Não se estará invadindo e desorganizando este espaço íntimo, onde as relações cotidianas das famílias foram construídas?

Muitos profissionais da saúde, com sua marcada autoridade profissional, vêem o paciente como uma pessoa desinformada que tem um problema a ser resolvido pela destruição do agente da doença, através de uma ação profissional.

Quando o paciente não adere ao tratamento é tido como ignorante, negligente ou preguiçoso, estimulando-se sua rotulação. Os fatores psicossociais, as crenças e as expectativas, a capacidade de compreensão, as habilidades de enfrentamento são considerados irrelevantes e não são objeto de preocupação desses profissionais.

Essa realidade, por sua vez, nos leva à uma triste conclusão: formar um profissional numa realidade que limita a autonomia dos pacientes e que considera desnecessária a ação de ouvir a pessoa doente pode tornar um potencial promotor de saúde e bem-estar em um mero cuidador de doenças.

A questão que surge nesse momento é: Como lutar contra uma crescente indiferença e desprezo pelo outro? A solução pode estar na união da competência com a consciência, o que exige responsabilidade ética do profissional da saúde. 
Para que o profissional da saúde ajude o próximo, ele deve ampliar o foco de suas ações fazendo a tomada de consciência quanto aos valores e princípios que sustentam suas ações.

Essas são algumas dentre as inúmeras questões que compõem o perfil desafiador do atendimento domiciliário, não só odontológico. Muitas são respondidas na prática, caso a caso, conduta a conduta, outras continuam objeto de incansável debate bioético, como o proposto pelo presente trabalho.

\subsection{A Bioética de modelo personalista: o que é e por que adotá-la}

Dentro de uma realidade pluralista, podem-se encontrar diversas visões do que deve ser considerado como correto. Dentre os diferentes modelos que buscam a fundamentação da bioética está o Personalismo (URBAN, 2003).

No momento de decidir qual será a intervenção mais adequada e como ela será feita, o profissional deve avaliar se o benefício esperado irá influenciar na qualidade de vida do paciente de forma positiva. O benefício, segundo o conceito hipocrático, é marcado pelo autoritarismo do profissional, que deverá fazer o bem e evitar o mal de acordo com seu entendimento.

A diferença para o conceito de benefício segundo o Modelo Personalista proposto por Sgreccia (1996) consiste no reconhecimento da dignidade das pessoas envolvidas, tanto do profissional como do paciente e sua família, visando o bem integral da pessoa, qualquer que seja a condição em que ela se encontre. Eis aí uma diferença fundamental entre esses dois modelos, necessária para que possamos compreender todas as considerações feitas a partir deste momento. 
O ENFOQUE CONFERIDO PELA BIOÉTICA DE MODELO PERSONALISTA AO ATENDIMENTO DOMICILIÁRIO

De acordo com $\operatorname{Ramos}^{17}$ (2005) a Bioética, ou a ética que se preocupa com a vida não é novidade. Entretanto, o modelo bioético personalista, ou Personalismo Ontologicamente Fundado nos propõe um fundamento: A pessoa humana, considerada em sua essência, em sua natureza, em sua verdade.

Ao centrar a questão na pessoa humana é importante frisar que nosso objeto de estudo fica focado em uma realidade que nós conhecemos, justamente a partir de nossas experiências elementares, pois cada um de nós é uma 'pessoa' (individualidade). Destaco este aspecto porque a reflexão que se segue tem como

método da verificação de veracidade a comparação com nossa própria experiência, com o 'eu' de cada ser. Mesmo que não possamos explicar integralmente cada um dos componentes do que vem a ser a pessoa humana, sabemos do que se trata.

O Modelo Personalista, proposto por Sgreccia (2003), considera que a pessoa humana é composta por uma unicidade, representada pela unidade entre corpo e espírito, que constitui a sua singularidade ou identidade. Segundo este autor, "a pessoa é, antes de tudo, um corpo espiritualizado, um espírito encarnado, que vale por aquilo que é e não somente pelas escolhas que faz" (RAMOS,2005) ${ }^{18}$.

O Personalismo realista vê na pessoa uma unidade, como é chamada freqüentemente uma totalidade de corpo e espírito, que representa o seu valor objetivo, pelo qual a subjetividade se responsabiliza, e não pode deixar de fazê-lo, quer em relação à própria pessoa quer em relação à pessoa do outro (SGRECCIA, 2003).

Esse é o primeiro ponto: a pessoa humana é uma unicidade ou, minimamente, uma singularidade ou identidade.

O segundo ponto consiste em reconhecemos que cada pessoa humana apresenta várias dimensões, minimamente: corpórea ou 
O ENFOQUE CONFERIDO PELA BIOÉTICA DE MODELO PERSONALISTA AO ATENDIMENTO DOMICILIÁRIO

física,psicológica, social ou moral. Cada uma delas tem sido objeto de estudo de diferentes ciências; a

dimensão corpórea ou física é objeto das ciências da saúde, as psicológica, social e moral, da psicologia, Filosofia, etc.

O modelo Personalista vai somar a estas dimensões a metafísica ou espiritual, objeto de estudo da Filosofia e da Teologia.

A pessoa humana, como ponto de referência da bioética personalista, é considerada um fim e não um meio, para a Ciências da Saúde. Isto porque tanto o objeto - paciente - quanto o sujeito - profissional da saúde - são pessoas, e estas devem ser consideradas na plenitude de seu valor (PACCINI, 2003).

O ser humano toma consciência de si no seu relacionamento com os outros. A comunicação e a solidariedade em sociedade referem-se à integração efetiva do homem numa sociedade concreta, na qual é chamado a intervir pela dimensão social do seu ser e o seu existir. Há, portanto, um apelo à responsabilidade social de cada pessoa na construção do verdadeiro humanismo (NEVES, 1996).

Ademais, para Neves (1996), a pessoa, na unidade integral do seu ser singular e na identidade universal da Humanidade do homem, torna-se o fundamento metafísico da ordem ética; e a antropologia pela autenticidade da sua singularidade, o único fundamento da bioética.

Eis os motivos pelos quais escolher o Modelo de Bioética Personalista para analisar a atuação do profissional da saúde, mais especificamente a atuação do Cirurgião-Dentista, quando da prestação de serviço de atendimento domiciliário a seus pacientes. Cabe, agora, analisar com um pouco mais de cuidado a ênfase dedicada ao respeito à dignidade da pessoa humana defendida por esse modelo bioético. 


\subsection{A bioética de modelo personalista: o respeito à dignidade da pessoa humana}

Dignidade, derivado do latim digitas (virtude, honra, consideração), em regra se estende à qualidade moral, que, possuída por uma pessoa, serve de base ao próprio respeito em que é tida. Compreende-se, também, como o próprio procedimento da pessoa, pelo qual se faz merecedor do conceito público (DE PLACIDO e SILVA, 2001).

Dallari (2004) nos ensina que qualquer ação humana que tenha algum reflexo sobre as pessoas e seu ambiente deve implicar o reconhecimento de valores e uma avaliação de como estes poderão ser afetados. O primeiro desses valores é a própria pessoa, com as peculiaridades que são inerentes à sua natureza, inclusive as suas necessidades materiais, psíquicas e espirituais. Ignorar essa valoração ao praticar atos que produzam efeitos sobre a pessoa humana, seja diretamente sobre ela ou através de modificações do meio em que a pessoa existe, é reduzir a pessoa à condição de coisa, retirando dela sua dignidade. Isso vale para qualquer tipo de ação: as ações do governo, as atividades que afetem a natureza, empreendimentos econômicos, ações individuais ou coletivas e, ainda, a criação e aplicação de tecnologia ou qualquer atividade no campo da ciência.

Entre os valores inerentes à condição humana está a vida. Assim, reconhecida a vida como um valor é que se chegou ao costume de respeitá-la, incorporando-a ao ethos de todos os povos, embora com algumas variações decorrentes de peculiaridades culturais ${ }^{19}$.

\footnotetext{
${ }^{19}$ Como leciona Norberto Bobbio (1992), os direitos humanos nascem como direitos naturais universais, desenvolvem-se como direitos positivos particulares (quando cada Constituição incorpora Declarações de Direitos), para finalmente encontrarem sua plena realização como direitos positivos universais. Ademais, inobstante a importância do debate a respeito do fundamento dos direitos humanos, como pondera Norberto Bobbio, o maior problema dos direitos humanos hoje "não é mais o de fundamentá-los, e sim o de protegê-los" . note-se que o Direito Internacional dos Direitos Humanos ergue-se no sentido de resguardar o valor da dignidade da pessoa humana, concebida como fundamento dos direitos humanos (PIOVESAN, 2002).
} 
João Paulo II afirma que "é na luz da dignidade da pessoa humana que se afirma por si mesma que a razão aprende o valor moral específico de alguns bens, para os quais a pessoa está naturalmente inclinada. E a partir do momento em que a pessoa humana não é redutível a uma liberdade que se auto projeta mas comporta uma estrutura espiritual e corpórea determinada, a existência originária de amar e respeitar a pessoa como um fim e nunca como um simples meio implica, também, intrinsecamente, o respeito a alguns bens fundamentais sem o qual se cai no relativismo e no arbítrio" (JOÃO PAULO II, 1992).

Sabe-se, todavia, que muitos profissionais da área da saúde tendem a reduzir a pessoa humana a um meio, ou à uma doença, ou, ainda, a um sucesso terapêutico. A pessoa deixa de ser considerada um fim em si, e passa a ser tida como um meio, na medida em que o fim é o sucesso ou o insucesso profissional da terapêutica. Essa postura é significativa do esquecimento do "eu", do "ser", uma postura niilista (RAMOS, 2001 - adaptado) ${ }^{20}$.

João Paulo II, analisando as ideologias do nosso tempo fala-nos do niilismo: "O niilismo, antes mesmo de estar em contraste com as exigências e os conteúdos próprios, é a negação da Humanidade do homem e também sua identidade, de fato é preciso ter em conta que o esquecimento do ser implica, inevitavelmente, a perda do contato com a verdade objetiva e, conseqüentemente, com o fundamento sobre o qual se apóia a dignidade do homem. Desse modo, abre-se espaço à possibilidade de apagar da face do homem os traços que revelam a sua semelhança com o infinito, com Deus, conduzindo-o progressivamente a uma destrutiva ambição de poder ou ao desespero da solidão. Uma vez que se privou o homem da verdade, é pura ilusão pretender torná-lo livre.

Verdade e liberdade com efeito caminham juntas, ou juntas miseravelmente perecem."(JOÃO PAULO II, 1998). 
O ENFOQUE CONFERIDO PELA BIOÉTICA DE MODELO PERSONALISTA AO ATENDIMENTO DOMICILIÁRIO

Temos evidenciado, portanto, a fundamentação do juízo bioético aqui proposto: o reconhecimento da identidade da pessoa e a dignidade humana, a partir dos quais pode-se enfrentar os princípios propostos pela bioética de modelo personalista ${ }^{21} \mathrm{e}$, ainda, ponto de partida para a análise do atendimento domiciliário odontológico.

Frise-se, por fim, que os direitos humanos, tais quais o direito à vida e o respeito à dignidade da pessoa humana, não são uma nova moral nem uma religião leiga, mas são muito mais do que um idioma comum para toda a Humanidade. São requisitos que o pesquisador deve estudar e integrar em seus conhecimentos utilizando as normas e métodos de sua ciência, seja ela a filosofia, as Humanidades, as ciências naturais, a sociologia, o direito, a história ou a geografia." (UNESCO, 1977).

\subsection{0 personalismo e 0 atendimento domiciliário odontológico}

Segundo o Código de ÉTICA OdonTOLÓGICA - CEO, Resolução CFO42, de 20 de maio de 2003, a "Odontologia deve ser exercida em benefício da saúde do ser humano e da coletividade, não havendo discriminação sob qualquer forma ou pretexto; o profissional deve zelar pela saúde e pela dignidade do paciente." Assim, buscar compreender a doença ou a circunstancia em que se encontra o paciente, procurar conhecer seus medos, suas aflições para realizar um atendimento dentro dos limites de cada paciente é trazer de volta para o tratamento odontológico a humanização, que é fundamental em todo serviço de saúde (RAMOS, 2002).

\footnotetext{
${ }^{21}$ Princípio da defesa da vida física, princípio da liberdade e responsabilidade, e princípio da sociabilidade e subsidiariedade (SGRECCIA, 1996).
} 
Do quanto exposto até o momento, torna-se cristalina a relação entre o modelo personalista de bioética e o atendimento domiciliário odontológico. Ora, a grande problemática que envolve o relacionamento profissional-paciente diz respeito ao modo com que lidamos com esse paciente: buscamos a cura da doença ou da pessoa? Olhamos para uma enfermidade ou para um ser humano? Procuramos adequar o tratamento odontológico domiciliário às necessidades do paciente ou às nossas próprias necessidades técnicocientíficas?

$\mathrm{Na}$ ânsia pela cura e levados, muitas vezes, pelo amor à profissão, o Cirugião-Dentista deixa de considerar os aspectos inerentes à integralidade da pessoa do paciente e passa a desenvolver técnicas e práticas que, em que pese o reconhecido valor científico, não são adequadas à situação psico-social em que o paciente se encontra.

Ademais, há que se trabalhar constantemente a educação do profissional no sentido de desprovê-lo de toda e qualquer forma de discriminação para com o paciente. Vale dizer, a discriminação significa toda distinção, exclusão, restrição ou preferência que tenha por objeto ou resultado prejudicar ou anular o exercício, em igualdade de condições, dos direitos humanos e liberdades fundamentais, nos campos político, econômico, social, cultural e civil, ou em qualquer outro campo. Logo, a discriminação significa sempre desigualdade. Daí a urgência em se erradicar todas as formas de discriminação, baseadas na raça, cor, descendência ou origem nacional ou étnica, que tenham como escopo a exclusão. Com efeito, a igualdade e a discriminação pairam sob o binômio inclusão-exclusão. Enquanto a igualdade pressupõe formas de inclusão social, a discriminação implica na violenta exclusão e intolerância à diferença e à diversidade (PIOVESAN, 2002).

Por essa razão, o enfoque conferido pela bioética de modelo personalista é de extrema importância para a prática odontológica no programa de atendimento domiciliário, pois somente ao considerar os outros, e a nós mesmos, como seres humanos inteiros, multifacetados e experimentadores de situações que 


\section{O ENFOQUE CONFERIDO PELA BIOÉTICA DE MODELO PERSONALISTA AO} ATENDIMENTO DOMICILIÁRIO

nos tornam únicos em toda a sociedade mundial, poderemos, de fato, promover a saúde daqueles que dela necessitam, nas esferas física, moral, psicológica e espiritual. 


\section{CONSIDERAÇÕES FINAIS}




\section{CONSIDERAÇÕES FINAIS}

Segundo Arras e Dubler (1994), o fato realmente novo com o advento do atendimento domiciliário, principalmente em relação ao uso da tecnologia, consiste na 'hipermedicalização,22 do domicílio. Para os autores, essa transferência das ações médico-odontológicas para a vida privada levanta questionamentos: "que tipo de casa e de família nós queremos que a sociedade adote, e a que preço?", pois corremos o risco de tornar alguns domicílios em "meros satélites de instituições médicas". Com isso, o olhar do atendimento domiciliário seria encarado apenas como uma mudança de local de tratamento e não como uma mudança de filosofia nos cuidados administrados ao paciente (COLLOPY; DUBLER; ZUCKERMAN, 1990).

Com efeito, a transformação do domicílio pela internação domiciliar, por exemplo, pode levar o atendimento domiciliário a ser um complexo fenômeno social que melhora a vida para muitos pacientes graves, minando para outros as condições que tendem a promover importantes benefícios sociais e oportunidades (ARRAS ; DUBLER, 1994).

Ademais, conforme bem observado por Ruddick (1995), há pacientes que preferem permanecer e receber determinados tratamentos em um ambiente hospitalar e, portanto, este desejo deve ser respeitado, principalmente quando a doença está em curso avançado, com deterioração física.

Outro aspecto a ser finalmente considerado refere-se ao fato de que os programas de atendimento domiciliário não necessariamente reduzem os custos, mas podem trazer benefícios para o paciente, a família e o cuidador, tais como o aumento na satisfação com a qualidade de vida e o aumento na

\footnotetext{
${ }^{22}$ A hipermedicalização no domicílio consiste na transferência, par o domicílio, de equipamentos hospitalares - nas hipóteses de intyernaçãop domiciliária -, atenção hospitalar - ações médicoodontológicas - e visita de equipe multiprofissional, periodicam,ente, necessária para cuidado do paciente.
} 
atenção e confiança em relação aos cuidados domiciliares. Esta foi uma das conclusões do National Long Term Care Demonstration (KEMPER, 1988), estudo multicêntrico realizado nos estados Unidos em 1982, que avaliou, durante um ano e seis meses, 6 (seis) mil idosos fragilizados inseridos em uma programa de atendimento domiciliar do tipo case management (atendimento médico ambulatorial, suporte telefônico contínuo e visitas no domicílio).

Tendo em vista as atividades exercidas pelo programa de atendimento domiciliário, não só odontológico, os interesses dos diversos atores, e o trabalho dirigido ao núcleo local do sistema de saúde, nos quais as políticas se traduzem em ações desenvolvidas pelos profissionais, cujos efeitos podem ser muitas vezes benéficos, mas outras indesejáveis sobre os destinatários do programa, foram suscitados questionamentos bioéticos, cuja finalidade é a de alinhar a visão dos gestores organizacionais por meio de um acordo sobre os projetos a serem desenvolvidos no futuro.

Para Weissert (1988), esses programas deveriam ser baseados nos benefícios ao usuário e não na possibilidade de redução de custos.

Esse posicionamento reflete um modelo baseado no utilitarismo.O modelo personalista, proposto por Sgreccia (1996), que tem como fundamento das relações estabelecidas entre profissional-paciente as pessoas humanas (do profissional e do paciente), e capaz de tornar o programa de atendimento domiciliário menos intervencionista e mais humanizado.

Devemos voltar nossa atenção para o entendimento das reais necessidades do paciente e de sua família, passando a tomar decisões guiadas pelo espírito de respeito à dignidade do ser humano e não com base em meros resultados econômicos.

Ora, encontra-se na Bioética o fundamento que orienta o caráter assistencial e humanitário da atividade desenvolvida na assistência domiciliária. Assim, cada profissional deve buscar desenvolver dentro de si uma ética que vise, 
antes e acima de tudo, o tratamento do paciente como um ser humano, que deve ser respeitado em toda sua dignidade.

Trata-se, aqui, de trabalhar sobre a construção de um pensamento baseado na valorização do Homem enquanto vida, visualizando-o em si mesmo, em sua totalidade, desprezando e evitando juízos de valores que representem qualquer forma de discriminação.

O fundamento dessa ética que os profissionais devem desenvolver deverá ser baseada em deixar o preconceito de lado sob qualquer pretexto e considerar o ser humano, ou melhor, mais especificamente no nosso caso, o paciente sob três premissas: realismo, racionalidade e moralidade. (SOLYMOS, 2002).

REALISMO, significa considerar que nosso conhecimento (equipe) em relação a outra pessoa (paciente e familiares/cuidadores) deve partir do objeto a ser conhecido e não dos métodos que conhecemos impostos a ele. De que forma o realismo se manifesta na assistência domiciliária? Manifesta-se quando o profissional observa todos os aspectos relacionados à realidade da família, a relação entre os familiares e o paciente, e a própria biografia do paciente.

RACIONALIDADE implica no uso da razão, ou seja, o método escolhido para o tratamento do paciente deve ser adequado ao contexto em que se insere toda a sua família. A razão deve seguir sempre o método adequado ao tipo de realidade que se quer conhecer. A título ilustrativo, não há que se pensar em qualquer tipo de intervenção técnica em um ambiente que não favorece tal intervenção. O que deve determinar, assim, o método técnico de se lidar com aquela situação é a realidade.

Com relação à MORALIDADE, entendemos que a equipe deve ter uma atitude justa diante do objeto (paciente). Via de regra, é possível dizer que o amor à verdade deve ser maior que o apego às opiniões que já temos (preconceito) sobre um determinado objeto. Esse amor à verdade passa, necessariamente, pelo amor ao objeto (paciente) de nossa ação; amor esse que 
tem como uma de suas fontes o próprio reconhecimento da dignidade. Surge aí uma importante reflexão sobre o amor à pessoa humana e o reconhecimento de sua dignidade.

Ademais, a moralidade, enquanto amor ao objeto (pessoa), está em contraposição a uma postura puramente pragmática, ou seja, essencialmente técnica e que suprime a existência de relações interpessoais que, conforme já visto, existem e devem ser consideradas para que se estabeleça um tratamento domiciliário eficaz ${ }^{23}$.

Isso nada mais é do que estimular a preservação de uma vida humana digna, seja ela breve ou longa, acometida por alguma doença ou tida como inteiramente sadia.

Esse é, assim, o propósito principal da Bioética Personalista aplicada à equipe multidisciplinar responsável pelo atendimento domiciliário: conferir aos seus pacientes bem-estar físico, moral, psíquico e espiritual, partilhando suas dores e suas esperanças.

Dentro desse contexto, o PAD-HU/USP é um avanço inconteste na humanização do tratamento dos pacientes impossibilitados de locomoção e promove a diminuição de agravamento por infecções cruzadas hospitalares. Ademais, o atendimento domiciliário odontológico favorece a inserção da Odontologia na equipe multiprofissional de saúde, onde seu papel traz ganho de qualidade para a manutenção da saúde do paciente e, conseqüentemente, para sua melhora.

Nesse cenário, que deve ser o mais coletivo possível, o enfoque conferido pela bioética de modelo personalista ao atendimento domiciliário permite não só a melhora da saúde bucal do paciente, como também contribui ao incentivar o respeito ao ser humano, enquanto pessoa única em corpo e espírito, promovendo em muitos casos uma sensível melhora do paciente.

\footnotetext{
${ }^{23}$ É importante frisar que a moralidade implica não só no sucesso da técnica utilizada no tratamento domiciliário, mas também na mudança da vida das pessoas vinculadas ao programa de atendimento domiciliário - família/paciente/profissional - na medida em que todos passam a valorizar uns aos outros enquanto pessoas humanas. Exemplo da melhora das relações interpessoais estabelecidas pelo programa foi a elaboração do filme produzido pelo $\mathrm{PAD} / \mathrm{HU}$ que, além de instruir cuidadores, demonstra de forma clara que a simplicidade e ausência de preconceitos são fatores fundamentais para satisfação dos pacientes, suas famílias e profissionais, onde todos se sentem protagonistas de ações que visam assegurar, acima de tudo, o respeito e a dignidade humana.
} 
Por fim, apesar de todas as dificuldades inerentes ao programa de atendimento domiciliário, aos atores e às crenças e preconceitos dos agentes, espera-se que a reflexão promovida pela bioética personalista ocupe um grande espaço no sentido de construir um cenário mais otimista (e humanizado) para o desempenho dessa tão importante atividade. 


\section{REFERÊNCIAS}




\section{REFERÊNCIAS ${ }^{24}$}

Albuquerque SMRM. Participação do serviço social em programas interdisciplinares de assistência domiciliar. Rev Serv Soc Hosp 1996;3(1):96.

Albuquerque SMRM. As práticas do serviço social na área da saúde. Rev Serv Soc Hosp 1997;4(1):97.

Alves EGR. Pedaços de mim: o luto vivido por pessoas com deformidade facial pós-trauma bucomaxilofacial e sua interferência no seu processo de desenvolvimento [Tese de Doutorado]. São Paulo: Instituto de Psicologia da USP; 2006.

Agência Nacional de Vigilância Sanitária (ANVISA). Consulta Pública n. 81 de 10 de outubro de 2003. Dispõe sobre o regulamento técnico contendo as normas de funcionamento de serviços que prestam assistência domiciliária. Disponível em: <http://www.anvisa.gov.br> (março 2006).

Araújo ME. Educação superior em odontologia na perspectiva das políticas públicas de saúde [Tese de livre-docência]. São Paulo: Faculdade de Odontologia da USP; 2004.

Arras J, Dubler NN. Bringing the hospital home: ethical and social implications of high-tech home care. Hestings Cent Rep 1994;24:S19-28.

Balera W. A seguridade social na constituição de 1988. São Paulo: Revista dos Tribunais; 1989.

Bandeira de Mello CA. Curso de direito administrativo. 13 Malheiros; 2001.

Beauchamp TL, Childress JF. Princípios de ética biomédica. Tradução de Luciana Pudenzi. São Paulo: Loyola; 2002.

Bellino F. Fundamentos da bioética: aspectos antropológicos, ontológicos e morais. Tradução de Nelson Souza Canabarro. Bauru: Edusc; 1997.

\footnotetext{
${ }^{24}$ De acordo com o estilo Vancouver. Abreviatura de periódicos segundo basas de dados MEDLINE.
} 
Berger L. A relação de ajuda em gerontologia. In: Berger L, Mailloux-Poiriér D. Pessoas idosas. Lisboa: Lusodidacta; 1995.

Bobbio N. A era dos direitos. Rio de Janeiro: Campos; 1992. p. 25-30.

Boff L. Prefácio. In: Palácios M, Martins A, Pegoraro O. Ética, ciência e saúde: desafios da bioética. Petrópolis: Vozes; 2002. p. 7-9.

Bontempo M. Medicina natural: medicina oriental. São Paulo: Nova Cultural; 1992.

Bosi, E. A questão do sujeito. In: João Augusto Frayze-Pereira;. (Org.). O pensamento cruel. 1 ed. São Paulo: Casa do Psicólogo, 2005, v. 1, p. 7-8

Botazzo C. da arte dentária. São Paulo: HUCITEC/FAPESP; 2000.

Botazzo C. Saúde bucal e cidadania: transitando entre a teoria e a prática. In: Pereira AC, organizador. Odontologia em saúde coletiva. Porto Alegre: ArtMed; 2003. cap. 1, p. 17-27.

Brasil. Ministério da Saúde. Secretaria de Políticas de Saúde. Política Nacional de Saúde do Idoso. Brasília; 1999.

Brunetti RF; Montenegro LFB._Odontogeriatria: Noções de Interesse Clínico. São Paulo: ArtMed; 2002. cap.7;p.99.

Carletti SMM, Rejani Ml. Atenção domiciliária ao paciente idoso. In: Papaléo Netto M. Gerontologia. São Paulo: Atheneu; 1996.

Carvalho GI, Santos L. Sistema único de saúde: comentários à lei orgânica de saúde. São Paulo: Hucitec; 1992.

Carvalho JM. Cidadania no Brasil: o longo caminho. Rio de Janeiro: Civilização Brasileira; 2002.

Ceschini M. Porque assistência domiciliar. In: Dias ELF, Wanderley JS, Mendes RT, organizadores. Orientações para cuidadores informais na assistência domiciliar. Campinas: Editora UNICAMP; 2002. cap. 1, p.11-16. 
Chauí M. Convite à filosofia. São Paulo: Ática; 1997.

Chaves MM. Ética nos serviços de saúde: ética no setor saúde. In: Palácios M, Martins A, Pegoraro O, organizadores. Ciência, ética e saúde: desafios da bioética. Rio de Janeiro: Vozes, 2001. p. 134-38.

Chaves MM. Odontologia social. 3aㅡ ed. São Paulo: Artes Médicas; 1986.

Collopy B, Dubler N, Zuckerman C. The ethics of. Homecare: autonomy and accomodation. Hastings Cent Rep 1990;20 Suppl:S1-16.

Cunha ICKO. Organização de serviços de assistência domiciliária de enfermagem [Dissertação de Mestrado]. São Paulo: Escola de Enfermagem da USP; 1991.

Dal Ben L. Assistencia domiciliar no Brasil. Dal Ben Home care [informe eletronic] 2003. Disponível em http://www.dalben.com.br., consultado em 23/04/2006.

Dallari DA. Bioética e direitos humanos. In: http://www.dhnet.org.br/direitos/militantes/dalmodallari/dallari Bio.html. 2004, consultado em 24/05/2006.

De Plácido e Silva. Vocabulário jurídico. 18ํe ed. Rio de Janeiro: Editora Forense; 2001.

Derani C. Privatização e serviços públicos: as ações do Estado na produção econômica. São Paulo: MaxLimonad; 2002. p. 61-75.

Di Pietro MSZ. Direito administrativo. 15ª ed. São Paulo: Atlas; 2002.

Duarte YAO, Diogo MJD'E. Atendimento domiciliar: um enfoque gerontológico. São Paulo: Atheneu; 2000.

Espinosa J. Questões de bioética. São Paulo: Editora Quadrante; 1998. p.10-8. 
Ferreira C. O que não é odontologia no programa de saúde da família. Jornal da ABORJ 2001 set., p.31.

Floriani CA, Schramm FR. Atendimento domiciliar ao idoso: problema ou solução? Cad Saúde Públ 2004:986-94.

Gomes JCM. Bases éticas do relacionamento médico-paciente. In: Urban CA. Bioética clínica. Rio de Janeiro: Revinter; 2003. cap. 20. p. 177-89.

Gonçalves ID. Direito previdenciário. São Paulo: Saraiva; 2005. p. 7-9.

Grotti DAM. Teoria dos serviços públicos e sua transformação. In: Sundfeld CA, organizador. Direito administrativo econômico. São Paulo: Malheiros; 2000. p. $39-46$.

Hospital das Clínicas de São Paulo. Manual do núcleo de atendimento domiciliário integrado. São Paulo: HCSP; 1995.

Ismael JC. O médico e o paciente: breve história de uma relação delicada. São Paulo: T.A. Queiroz; 2002.

Jacob Filho W, Chiba T, Andrade MV. Assistência domiciliária interdisciplinar em uma instituição de ensino. In: Duarte YAO, Diogo MJD'E. Atendimento domiciliar: um enfoque gerontológico. São Paulo: Atheneu; 2000.

João Paulo II. Carta Encíclica Veritas Splendor; 1992.

João Paulo II. Carta Encíclica Fides et Ratio; 1998.

Jorge, W A; Alves, T F; Milani, B A; Foronda, R. Incidência de pacientes internados por infecções odontogênicas no HU-USP. Pesquisa Odontológica Brasileira, São Paulo, v. 17, n. 2, p. 57, 2003.

Kassab GEF. A assistência domiciliária (AD) no Hospital do Servidor Público Estadual de São Paulo: hospital Dr. Francisco Moratto de Oliveira. In: Duarte YAO, Diogo MJD'E. Atendimento domiciliar: um enfoque gerontológico. São Paulo: Atheneu; 2000. 
Kemper P. Evaluation of. The nacional long term of. Care demonstration 10. Overview of. The findings. Health Serv Res 1988;23:161-74.

Leme LEG. A interprofissionalidade e o contexto familiar. In: Duarte YAO, Diogo MJD'E. Atendimento domiciliar: um enfoque gerontológico. São Paulo: Atheneu; 2000. cap. 10, p.117-43.

Lemos ND. O idoso e a família em programas de assistência domiciliar: o papel do assistente social neste contexto. Gerontologia. Sociedade Brasileira de Geriatria e Gerontologia de São Paulo [periódico on-line];Disponível em http://www.sbgg.sp.com.br/?destino=secoesfixashome\&idsecao=2 $\left[\begin{array}{ll}13 & \text { jun. }\end{array}\right.$ 2003].

Liener PC. Hierarquia e Individualismo. Ed. Jorge Zahar. São paulo: 2003.

Martins MCFN. Humanização das relações assistenciais: a formação do profissional de saúde. São Paulo: Casa do Psicólogo; 2001.

Mazza MMPR. Visita domiciliária como instrumento de assistência de saúde. Rev Bras Cresc Des Hum 1994;4(2):60-8.

Medauar O. Direito administrativo moderno. 4a ed. São Paulo: Revista dos Tribunais; 2000.

Melo MM. As diretrizes curriculares nacionais e os cursos paranaenses de odontologia: processo de construção e perspectivas de implementação [Dissertação de Mestrado]. Londrina: Centro de Ciências da Saúde da UEL; 2004.

Mill JS. Utilitarismo. 1aㅡ edição da Gradiva. Lisboa: 2005.

Minayo MCS, organizador. Pesquisa social: teoria, método e criatividade. 14a ed. Rio de Janeiro: Vozes; 1995.

Minidicionário da língua portuguesa. São Paulo: Melhoramentos; 1996.

Monteiro CP, Monteiro JL. Internação domiciliária. In: Duarte YAO, Diogo MJD’E. Atendimento domiciliar: um enfoque gerontológico. São Paulo: Atheneu; 2000. p. 584. 
Moreira MPS. A avaliação social do idoso dependente na assistência domiciliar [Dissertação de Mestrado]. São Paulo: Departamento de Serviço Social da PUC; 2005.

Neri AL. Palavras-chave em gerontologia. Campinas: Alínea; 2001.

Neves MCP. A fundamentação antropológica da bioética. Bioética 1996;4(1):716.

Paccini R. Bioética personalista aplicada à clínica. In: Urban, CA. Bioética clínica. Rio de Janeiro: Revinter; 2003. cap. 8, p. 55-62.

Palácios $M$, Martins $A$, Pegoraro $O$, organizador. Ciência, ética e saúde: desafios da bioética. Rio de Janeiro: Vozes; 2001.

Papaléo Netto M, Tieppo A. Serviços de Assistência domiciliária da clínica geronto-geriátrica do Hospital do Servidor Público Municipal de São Paulo. In: Duarte YAO, Diogo MJD'E. Atendimento domiciliar: um enfoque gerontológico. São Paulo: Atheneu; 2000.

Pegoraro OA. Ética e ciência - fundamentos filosóficos da bioética. In: Palácios M, Martins A, Pegoraro O, organizador. Ciência, ética e saúde: desafios da bioética. Rio de Janeiro: Vozes, 2001. p. 46-61.

Piovesan F. Direitos humanos e o direito constitucional internacional. São Paulo: MaxLimonad; 2002.

Potter VR. Bioethics: the science of survival. Perspect Biol Med 1971:127-53.

Ramos DLP. Fundamentos e princípios da bioética. Notandum 2002;5(9):37-46. Disponível em: http://www.hottopos.com/notand9/dalton.htm. [11/04/06].

Rosenthal E. A odontologia no Brasil no séc. XX - história ilustrada. São Paulo: Santos; 2001. 
Ruddick W. Transforming homes and hospitals. In: Arras J, editor. Bringing the hospital home: ethical and social implications of. high-tech home care. Baltimore: The Johns Hopkins University Press; 1995. p. 166-79.

Santos WG. Cidadania e justiça: a política social na ordem brasileira. Rio de Janeiro: Campos; 1979.

Schramm FR. As diferentes abordagens da bioética. In: Palácios $M$, Martins $A$, Pegoraro $\mathrm{O}$, organizadores. Ciência, ética e saúde: desafios da bioética. Rio de Janeiro: Vozes; 2001. p. 28-45.

Schramm FR. Bioética para que? Rev Camiliana Saúde 2002;1:14-21.

Segre M. Considerações sobre o princípio da autonomia. Medicina Ribeirão Preto 1995;28(1):10-5.

Segre M. Ética em saúde. In: Palácios M, Martins A, Pegoraro O, organizadores. Ciência, ética e saúde: desafios da bioética. Rio de Janeiro: Vozes; 2001. p. 1927.

Sgreccia E. Manual de bioética: I - fundamentos e ética biomédica. São Paulo: Loyola; 1996.

Sgreccia E. A bioética e o novo milênio. Bauru: EDUSC; 2000.

Sgreccia E. Manuale di bioética: fondamenti ed. ética biomédica. $3^{\mathrm{a}}$ ed. Milano: Vita e Pensiero; 2003. 817 p.

Shirota M, Araujo ME. Observação das características do atendimento odontológico no Brasil - PNAD - 1998 [resumo PA79]. RPG 2001;(8):263.

Souza AA. Saúde em casa integra saúde bucal. Rev Odontol Brás 1998;6(23). Disponível em: http://www.cfo.org.br/jornal/n23/hpbrasil). [26 abr. 2006].

Sportello EF. Caracterização das formas de vida e trabalho das cuidadosas familiares do Programa de Assistência Domiciliária do Hospital Universitário da Universidade de São Paulo [Dissertação de Mestrado]. São Paulo; Escola de Enfermagem da USP; 2003. 
Sportello EF, Okano HIH, Follador NN. Perfil dos cuidadores do Programa de Assistência Domiciliária do HU-USP. In: Anais do 53ํㅡㄹ Congresso Brasileiro de Enfermagem; 2001 out. Curitiba [CD ROM]. Curitiba: ABEn-Seção-PR; 2001.

Tersariol A. Minidicionário brasileiro. São Paulo: Edelbra; 1997.

Timi JRR. Direitos do paciente. In: Urban CA. Bioética clínica. Rio de Janeiro: Revinter; 2003. cap. 24, p. 205-18.

Topinková E. Family caregiving for the elderly: are there ways to meet the need? In: Callahan D, Meulen RHJ, Tupinková E, editors. A Word growing old: the coming Walt care challenges. Washington, DC: Georgetown university Press: 1995. p. 106-16.

Unesco. Medium-term plan 1977-1982. Genebra: UNESCO; 1977. parágrafo 1122. (Documento $19 \mathrm{C} / 4$ ).

Urban CA. Introdução à bioética. Rio de Janeiro: Revinter; 2003. cap. 1, p. 3-10.

Veras RP. Terceira idade: gestão contemporânea em saúde. Rio de Janeiro: Relume Dumará: UnATI/UERJ; 2002.

Waldow VR. Cuidado humano: o resgate necessário. $3^{\underline{a}}$ ed. Porto Alegre: Sagra Luzzato; 2001.

Weissert WG. The nacional channeling demonstration: what we knew, know and steel need to know. Health Serv Res 1988;23:175-87.

Yamamoto TT, Sportello EF, Oliveira MAC. Caracterização dos pacientes atendidos pelo Programa de Assistência Domiciliária do HU-USP. Rev HU-USP 2002;12(1/2):26-34.

Yuaso DR, Sguizzatto GT. Serviço de assistência domiciliária ao idoso (SADI) do Centro de Referência à Saúde do Idoso do município de Guarulhos. In: Duarte YAO, Diogo MJD’E. Atendimento domiciliar: um enfoque gerontológico. São Paulo: Atheneu; 2000. 


\section{BIBLIOGRAFIA CONSULTADA}

ALMEIDA, M.B.; SPORTELLO, E.F.; REINACHER, A.S.; MOREIRA, M.P.S.; JORGE, M.D.; SILVA, S.N.P.; SAKURADA, C.K. Caracterização do Programa de Oxigenoterapia Domiciliar do HU-USP. São Paulo: Hospital Universitário da Universidade de São Paulo, 2003a. Mimeografado.

Bosi, E. Memória e sociedade-13.a edição. 13. ed. São Paulo: Companhia das Letras, 2005.

Brasil. Ministério da Saúde. Secretaria de Assistência à Saúde: Portaria número 2416. Mar. 1998.

Dias ELF, Wanderley JS, Mendes RT, organizadores. Orientações para cuidadores informais na assistência domiciliar. Campinas: Editora UNICAMP; 2002.

Dualibi SE. Pacientes especiais. In: Rosenthal E. A odontologia no Brasil no século XX - história ilustrada. São Paulo: Santos; 2001. p. 219-24.

Lucato MC. A humanização das relações assistenciais no código de ética odontológica - resolução 42/2003, de 20 de maio de 2003 [Dissertação de Mestrado]. São Paulo: Faculdade de Odontologia da USP; 2005.

Monetta L. A Especialidade no atendimento domiciliário. São Paulo: Editora Atheneu; 2000.

Narvai PC. Odontologia e saúde bucal coletiva. 2ª ed. São Paulo: Santos; 2002.

Narvai PC. Recursos humanos em saúde. In: Kriger L, organizador. ABOPREV: promoção de saúde bucal: paradigma, ciência e humanização. São Paulo: Artes Médicas; 2003.

Neri AL. Bem-estar e estresse em familiares que cuidam de idosos fragilizados e de alta dependência. In: Neri AL, organizador. Qualidade de vida e idade madura. Campinas: Papirus Editora; 2000. p. 237-85. 
Pessini L, Barchifontaine CP, organizadores. Fundamentos da bioética. São Paulo: Paulus; 1996.

Pessini L, Barchifontaine CP. Progresso tecnocientífico, medicina e humanização. In: Problemas atuais da bioética. 6aㅡ ed. São Paulo: Loyola; 2002.

Pessini L, Pereira LL, Zaher VL, Silva MJP. Humanização em saúde: o resgate do ser com competência científica. O mundo Saúde 2003;27(2):203-05.

Pessini L, Bertachini L. Humanização e cuidados paliativos. São Paulo: Loyola; 2004.

Ramos DLP. Perspectivas bioéticas na atenção à saúde bucal. In: Fortes PAC, Zoboli ELC. Bioética e saúde pública. São Paulo: Loyola; 2003. p. 161-7.

Ramos DLP, Luccato MC. A bioética e a humanização das relações assistenciais. Implant News 2004;1:(6):508-9.

Sawaya S M. Abordagem pedagógica, livro 5. In: Solymos GMB, Sawaya AL, organizadores. Coleção vencendo a desnutrição. São Paulo: Salus Paulista; 2002. Disponível em: http://www.desnutricao.org.

Siqueira JE, Prota L, Zancanaro L. Bioética: estudo e reflexões. Londrina: Editora Universidade Estadual de Londrina; 2001. v. 1-3.

Soares MLPV. Abordagem social, livro 4. In: Solymos GMB, Sawaya AL, organizadores. Coleção vencendo a desnutrição. São Paulo: Salus Paulista; 2002. Disponível em: http://www.desnutricao.org. [data de acesso].

Solymos GMB; Sawaya AL; Ferrari AA; Vieira MFA, Unegru CH. Centro de Recuperação e Educação Nutricional: uma proposta para o combate à desnutrição energético-protéica. In: Sawaya AL, organizador. Desnutrição urbana no Brasil em um período de transição. São Paulo: Cortez; 1997. p. 191.

Solymos GMB. Abordagem psicológica, livro 6. In: Solymos GMB, Sawaya AL, oranizadores. Coleção vencendo a desnutrição. São Paulo: Salus Paulista; 2002. Disponível em: http://www.desnutricao.org, consultado em 16/02/2005.

Sundfeld CA, organizador. Direito administrativo econômico. São Paulo: Malheiros; 2000. 
Toledo EHR, Diogo MJD'E. Elderly with hematological neoplasic disorders: actions and difficulties related to self-care at the beginning of the disease. Rev Latino-Am Enfermagem 2003;11(6):707-12.

Yuaso DR Cuidar de cuidadores: resultados de um programa de treinamento realizado em domicílio. In: Neri AL, organizadora. Cuidar de idosos no contexto da família: questões psicológicas e sociais. Campinas: Alínea; 2002. p. 165-201. 


\section{ANEXO A}

\section{FLUXOGRAMA DE ASSISTÊNCIA DOMICILIÁRIA DO PAD-HU/USP}

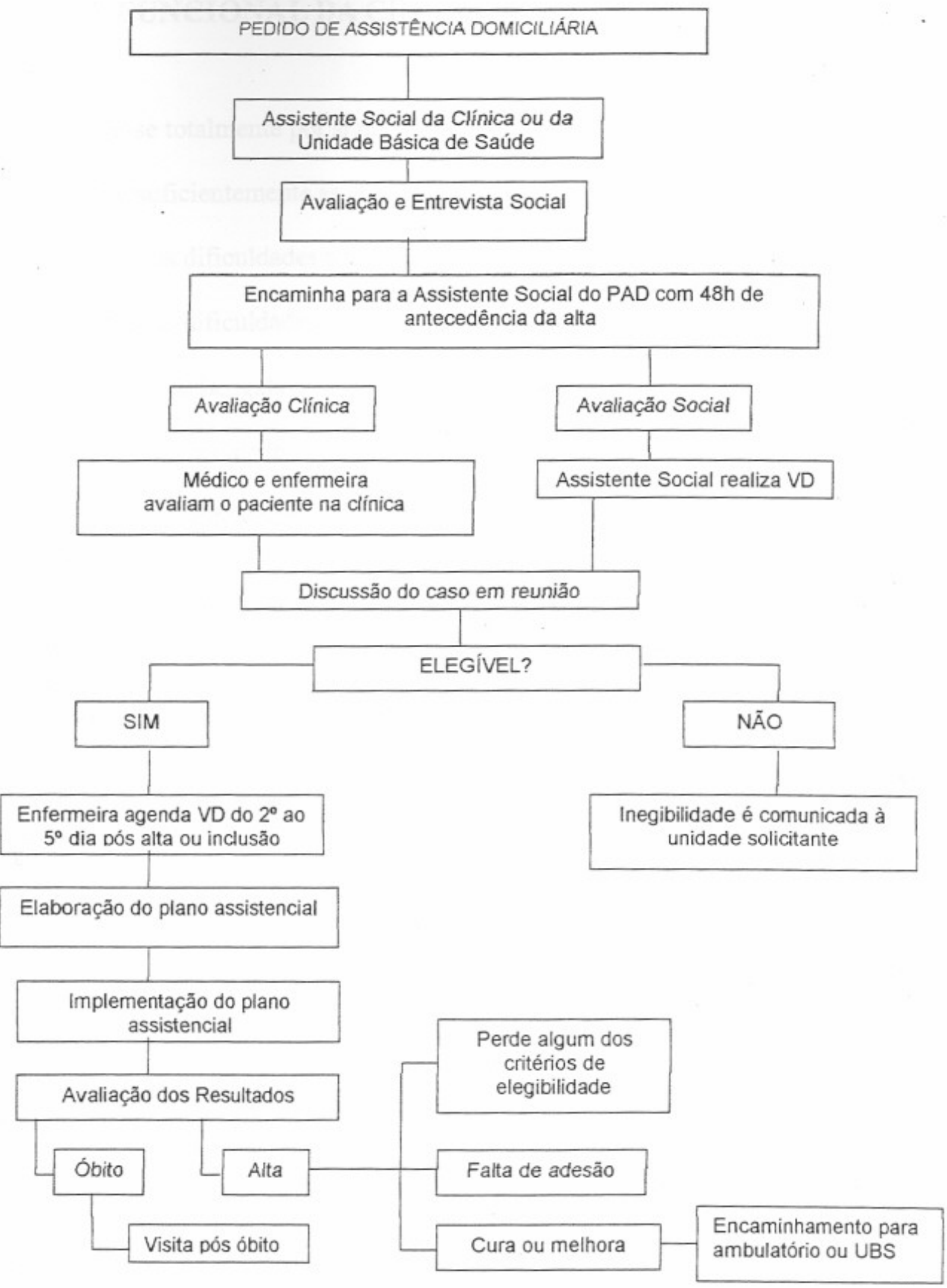




\section{ANEXO B \\ ESCALA DE AVALIAÇÃO DA INCAPACIDADE FUNCIONAL DA CRUZ VERMELHA ESPANHOLA}

0- Vale-se totalmente por si mesmo. Caminha normalmente.

Realiza suficientemente as atividades da vida diária (AVD).

1- Algumas dificuldades para locomoções complicadas.

2- Algumas dificuldades nas AVD, necessitando apoio ocasional. Caminha com ajuda de bengala ou similar.

3- Graves dificuldades nas AVD, necessitando apoio em quase todas.

Caminha com muita dificuldade, ajudado pelo menos por uma pessoa.

4- Impossível realizar, sem ajuda, qualquer das AVD. Capaz de caminhar, com extraordinária dificuldade, ajudado pelo menos por duas pessoas.

5- Imobilizado na cama ou sofá, necessitando cuidados contínuos. 


\section{ANEXO C}

\section{ESCALA DE BRADEN}

\begin{tabular}{|c|c|c|c|c|}
\hline $\begin{array}{l}\text { Percepção sensorial: } \\
\text { Capacidade de reagir } \\
\text { significativamente à } \\
\text { pressão relacionada } \\
\text { ao desconforto }\end{array}$ & \begin{tabular}{|l|} 
1. Totalmente limitado: \\
não reage (não geme, não se segura a \\
nada, não se esquiva) a estímulo \\
doloroso, devido ao nível de consciência \\
diminuido ou devido a sedação ou \\
capacidade limitada de sentir dor na \\
maior parte do corpo
\end{tabular} & $\begin{array}{l}\text { 2. Muito limitado: } \\
\text { Somente reage a estímulo doloroso. Não } \\
\text { é capaz de comunicar desconforto exceto } \\
\text { através de gemido ou agitação. Ou possui } \\
\text { alguma deficiência sensorial que limita a } \\
\text { capacidade de sentir dor ou desconforto } \\
\text { em mais de metade do corpo. }\end{array}$ & \begin{tabular}{|l|} 
3. Levemente limitado: \\
Responde a comando verbal, mas nem \\
sempre é capaz de comunicar o desconforto \\
ou expressar necessidade de ser mudado de \\
posição ou tem um certo grau de deficiência \\
sensorial que limita a capacidade de sentir \\
dor ou desconforto em 1 ou 2 extremidades. \\
\end{tabular} & $\begin{array}{l}\text { 4. Nenhuma limitação. } \\
\text { Responde a comandos verbais: não tem } \\
\text { déficit sensorial que limitaria a } \\
\text { capacidade de sentir ou verbalizar dor ou } \\
\text { desconforto }\end{array}$ \\
\hline $\begin{array}{l}\text { Umidade: } \\
\text { Nível ao qual a pele } \\
\text { é exposta a umidade }\end{array}$ & $\begin{array}{l}\text { 1. Completamente molhada: } \\
\text { A pele é mantida molhada quase } \\
\text { constantemente por transpiração, urina, } \\
\text { etc. Umidade é detectada às } \\
\text { movimentações do paciente. }\end{array}$ & $\begin{array}{l}\text { 2. Muito molhada: } \\
\text { A pele está freqüentemente, mas nem } \\
\text { sempre molhada. A roupa de cama deve } \\
\text { ser trocada pelo menos uma vez por } \\
\text { turno. }\end{array}$ & $\begin{array}{l}\text { 3. Ocasionalmente molhada: } \\
\text { A pele fica ocasionalmente molhada } \\
\text { requerendo uma troca extra de roupa de } \\
\text { cama por dia }\end{array}$ & $\begin{array}{l}\text { 4. Raramente molhada: } \\
\text { A pele geralmente está seca, a troca de } \\
\text { roupa de cama é necessária somente nos } \\
\text { intervalos de rotină. }\end{array}$ \\
\hline $\begin{array}{l}\text { Atividade: } \\
\text { Grau de atividade } \\
\text { física }\end{array}$ & $\begin{array}{l}\text { 1. Acamado: } \\
\text { Confinado a cama. }\end{array}$ & $\begin{array}{l}\text { 2. Confinado à cadeira: } \\
\text { Cápacidade de andar está severamente } \\
\text { limitada ou nula. Não é capaz de } \\
\text { sustentar o próprio peso e/ou precisa ser } \\
\text { ajudado a se sentar. }\end{array}$ & $\begin{array}{l}\text { 3. Anda ocasionalmente: } \\
\text { Anda ocasionalmente durante o dia, embora } \\
\text { distâncias muito curtas, com ou sem ajuda. } \\
\text { Passa a maior parte de cada turno na cama } \\
\text { ou na cadeira. }\end{array}$ & $\begin{array}{l}\text { 4. Anda freqüentemente: } \\
\text { Anda fora do quarto pelo menos } 2 \text { vezes } \\
\text { por dia e dentro do quarto pelo uma vez } \\
\text { a cada } 2 \text { horas durante as horas em que } \\
\text { está acordado. }\end{array}$ \\
\hline $\begin{array}{l}\text { Mobilidade: } \\
\text { Capacidade de } \\
\text { mudar e controlar a } \\
\text { posição do corpo }\end{array}$ & $\begin{array}{l}\text { 1. Totalmente imóvel: } \\
\text { Não faz nem mesmo pequenas } \\
\text { mudanças na posição do corpo ou } \\
\text { extremidades sem ajuda. }\end{array}$ & $\begin{array}{l}\text { 2. Bastante limitado: } \\
\text { Faz pequenas mudanças ocasionais na } \\
\text { posição do corpo ou extremidades mas é } \\
\text { incapaz de fazer mudanças freqüentes ou } \\
\text { significantes sozinho. }\end{array}$ & $\begin{array}{l}\text { 3. Levemente limitado: } \\
\text { Faz freqüentes, embora pequenas, } \\
\text { mudanças na posição do corpo ou } \\
\text { extremidades sem ajuda. }\end{array}$ & $\begin{array}{l}\text { 4. Não apresenta limitações: } \\
\text { Faz importantes e freqüentes mudanças } \\
\text { sem auxilio. }\end{array}$ \\
\hline $\begin{array}{l}\text { Nutrição: } \\
\text { Padrão usual de } \\
\text { consumo alimentar }\end{array}$ & $\begin{array}{l}\text { 1. Muito pobre: } \\
\text { Nunca come uma refeição completa. } \\
\text { Raramente come mais de } 1 / 3 \text { do } \\
\text { alimento oferecido. Come } 2 \text { porções ou } \\
\text { menos de proteína (carnes ou laticínios) } \\
\text { por dia. Ingere pouco líquido. Não } \\
\text { aceita suplemento alimentar líquido. Ou } \\
\text { é mantido em jejum e/ou mantido com } \\
\text { dieta líquida ou IVS por mais de cinco } \\
\text { dias. }\end{array}$ & $\begin{array}{l}\text { 2. Provavelmente inadequado: } \\
\text { Raramente come uma refeição completa. } \\
\text { Geralmente come cerca de metade do } \\
\text { alimento. Ingestão de proteína inclui } \\
\text { somente } 3 \text { porções de carne ou laticínios } \\
\text { por dia. } \\
\text { Ocasionalmente aceitará um suplemento } \\
\text { alimentar ou recebe abaixo da quantidade } \\
\text { satisfatória de dieta líquida ou } \\
\text { alimentação por sonda. }\end{array}$ & $\begin{array}{l}\text { 3. Adequado: } \\
\text { Come mais da metade da maioria das } \\
\text { refeições. Come um total de } 4 \text { porções de } \\
\text { alimento rico em proteínas (carne e } \\
\text { laticínios) todo dia. Ocasionalmente recusará } \\
\text { uma refeição, mas geralmente aceitará um } \\
\text { complemento oferecido. Ou é alimentado } \\
\text { por sonda ou regime de nutrição parenteral } \\
\text { total, o qual provavelmente satisfaz a maior } \\
\text { parte das necessidades nutricionais. }\end{array}$ & $\begin{array}{l}\text { 4. Excelente: } \\
\text { Come a maior parte de cada refeição. } \\
\text { Geralmente ingere um total de } 4 \text { ou mais } \\
\text { porções de carne e laticínios. } \\
\text { Ocasionalmente come entre as refeições. } \\
\text { Não requer suplemento alimentar. }\end{array}$ \\
\hline $\begin{array}{l}\text { Friç̧ão e } \\
\text { cisalhamento }\end{array}$ & $\begin{array}{l}\text { 1. Problema: } \\
\text { Requer assistência moderada a máxima } \\
\text { para se mover. É impossivel levantá-lo } \\
\text { ou erguê-lo completamente sem que } \\
\text { haja atrito da pele com o lençol. } \\
\text { Freqüentemente escorrega na cama ou } \\
\text { cadeira, necessitando freqüentes } \\
\text { ajustes de posiçãáo com o máximo de } \\
\text { assistência. Espascticidade, contratura } \\
\text { ou agitação leva a quase constante } \\
\text { fricção. }\end{array}$ & $\begin{array}{l}\text { 2. Problema em potencial. } \\
\text { Move-se mas, sem vigor ou requer } \\
\text { mínima assistência. Durante o movimento } \\
\text { provavelmente ocorre um certo atrito da } \\
\text { pele com o lençol, cadeira ou outros. Na } \\
\text { maior parte do tempo mantém posição } \\
\text { relativamente boa na cama ou na cadeira } \\
\text { mas ocasionalmente escorrega. }\end{array}$ & $\begin{array}{l}\text { 3. Nenhum problema: } \\
\text { Move-se sozinho na cama ou cadeira e tem } \\
\text { suficiente força muscular para erguer-se } \\
\text { completamente durante o movimento. } \\
\text { Sempre mantém boa posição na cama ou na } \\
\text { cadeira. }\end{array}$ & 4. \\
\hline
\end{tabular}




\section{ANEXO D}

\section{CLASSIFICAÇÃO DOS PACIENTES PAD/HU - USP ODONTOLOGIA}

\begin{tabular}{|c|c|c|}
\hline Nível & Quadro Clínico & Visitas \\
\hline I & $\begin{array}{c}\text { Primeira VD - exame clínico e busca ativa } \\
\text { de lesões / Orientaçóes gerais de higiene / } \\
\text { Prognóstico e Tratamento. }\end{array}$ & Avaliação inicial \\
\hline II & $\begin{array}{c}\text { Pacientes com quadros urgenciais que } \\
\text { necessitem procedimentos cirúrgicos e } \\
\text { periodontais específicos / Odontalgias em } \\
\text { geral encaminhamentos para o Serviço } \\
\text { de Urgência BMF-HU / Pacientes com } \\
\text { necessidade imediata de ajuste de } \\
\text { próteses }\end{array}$ & Visitas semanais \\
\hline III & $\begin{array}{c}\text { Pacientes com quadros clínicos de } \\
\text { manutenção e controle / Pacientes com } \\
\text { SNG }\end{array}$ & Visita quinzenal \\
\hline IV & $\begin{array}{c}\text { Pacientes com necessidade de } \\
\text { manutenção de próteses. }\end{array}$ & Visita mensal \\
\hline V & $\begin{array}{c}\text { Pacientes que não usam qualquer tipo de } \\
\text { prótese / dentes ausentes / Pacientes } \\
\text { estáveis. }\end{array}$ & Visita trimestral \\
\hline
\end{tabular}




\section{ANEXO E}

FICHA DE AVALLAÇĀO SOCIAL

\section{IDENTIFICAÇÃO DO PACIENTE}

Nome:

ID:

D. N:

Endereço:

Bairro:

CEP:

Cidade:

AT.

$\mathrm{HU}$ :

Mat.HU: Mat.UBS:

Sexo: $M($ ) $F($ ) Cor: Estado Civil: Religiāo:

Ponto de Referência:

Fone Residencial:

Outros:

FUNCIONÁRIO USP $\rightarrow$ Inativo ( ) Ativo ( ) Unidade: Função:

Dependente de Funcionário USP( ) Nome:

Parentesco: Unidade: Função: Ramal:

\section{PROCEDÊNCIA}

$\mathrm{HU} \rightarrow$ ( ) Enfermaria ( ) Ambulatório ( ) Pronto Atendimento CLínICA: PSF $\rightarrow$ Boa Vista ( ) Centro de Saúde Escola Butantā ( ) Vila Dalva ( ) São Jorge ( ) Paraisópolis ( ) Especialidade:...

Legenda para clinica e especialidade: CM (Clínica Médica) CC (Clinica Cinúrgica) CP (Clínica Pediátrica) CO (Clinica Obstétrica) Gen (Generalista)

\section{RECURSOS DE SAÚDE UTILIZADOS}

Unidade Básica de Saúde Ambulatório de Espacialidades

Hospital/Pronto Socorro. Plano de Saúde. Particular 
5. COMPOSIÇÃO FAMILIAR DO DOMICÍLIO

\begin{tabular}{|l|l|l|l|l|l|}
\hline NOME & PARENTESCO & IDADE & $\begin{array}{c}\text { GRAU DE } \\
\text { INSTRUÇĀO }\end{array}$ & OCUPAÇĀO & $\begin{array}{c}\text { RENDA } \\
\text { (SM) }\end{array}$ \\
\hline & & & & & \\
\hline & & & & & \\
\hline & & & & & \\
\hline & & & & & \\
\hline
\end{tabular}

Legenda para Grau de instrução: A (alfabetizado) SA (semi-alfabetizado) NA (não alfabetizado) EF (ensino fundamental) EM (ensino médio) ES (ensino superior) C (completo) I (incompleto)

Obs.: Mencionar nos casos de EF, EM e ES se, Completo ou Incompleto / no caso do ES, mencionar também o curso.

\section{SITUAÇÃO HABITACIONAL}

BARRACO: Térreo ( ) Sobrado ( ) CASA: Térrea ( ) Sobrado ( ) APARTAMENTO ( ) SITUAÇĀO: Própria ( ) Cedida ( ) por..................Alugada ( ) R\$................Financiada R\$.....

TIPO DE CONSTRUÇÄO: Alvenaria（） Madeira ( ) Bloco ( ) Outro ( ).

ACESSO: Elevador ( ) Escada( ) No Degraus/andares.

CÔMODOS: Sala (') Cozinha( ) Dormitórios ( )

BANHEIRO: Interno ( ) Externo( ) Unifamiliar: Sim( ) Năo( )

\section{ACOMODAÇÃO DO PACIENTE}

Cômodo destinado:

Acomodado em:

Banheiro privativo:

\section{Quarto ( ) Sala ( )}

Cama hospitalar ( )

Sofá ( ) Berço ( )

$\operatorname{Sim}($ ) Não( )

\section{EQUIPAMENTOS DE APOIO}

Cadeira de rodas ( ) Cadeira de banho( ) Andador ( ) inalador ( ) Rampa ( )

Aspirador ( ) Oxigênio/Concentrador ( ) Cama Hospitalar ( ) Outros ( )

Legenda: $P$ (próorio) L (locado) E (emprestado) D (Doado)

Obs.: Mencionar a procedència (empresa que loca ou pessca que emprestouldoou, etc.)

\section{MEIO DE TRANSPORTE}

Próprio( ) Parentes( ) Amigos( ) Prefeitura( ) Táxi( ) Transporte Coletivo ( ) Resgate( ) Nenhum( ) 


\section{CUIDADOR (ES)}

Nome: Idade:

Grau Parentesco:

Mesmo endereço do paciente $\operatorname{Sim}($ ) Năo ( ) Remunerado Năo( ) Sim( ) RS

Treinamento formal

$\operatorname{Sim}($ ) Não( )

Já cuidava do paciente

$\operatorname{Sim}($ ) Não( ) Há quanto tempo:

Obs:

Nome:

Idade:

Grau Parentesco:

Mesmo endereço do paciente $\operatorname{Sim}($ ) Não ( ) Remunerado Não( ) Sim( ) R\$

Treinamento formal

$\operatorname{Sim}($ ) Năo ( )

Já cuidava do paciente

Sim( ) Não( ) Há quanto tempo:

Obs:

\section{OBSERVAÇÕES}

\section{PARECER DA ASSISTENTE SOCIAL}

ELEGIVEL （ )

INELEGIVEL （） MOTIVO: 


\section{ANEXO F \\ PEDIDO DE ASSISTÊNCIA DOMICILIÁRIA DO PAD-HU}

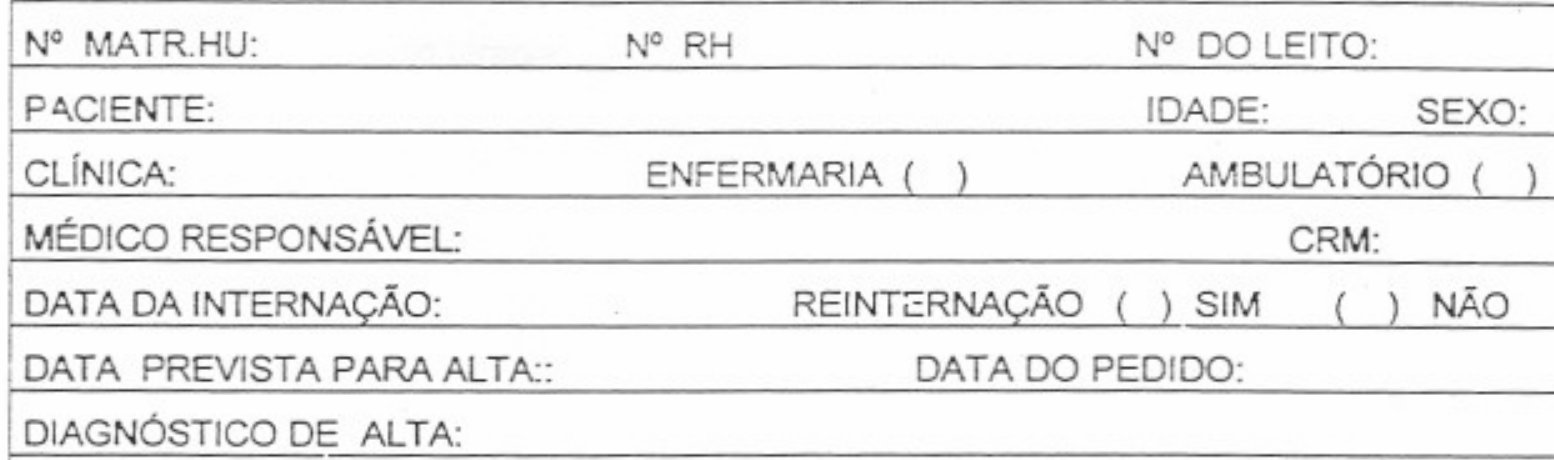

RESUMO CLINICO:

MEDICAÇĀO PRESCRITA PARA ALTAVPOSOLOGIA:

CUIDADOS NECESSÁRIOS:

CURATIVOS:

ÚlCERA DE PRESSĀO: ( ) NĀO ( ) SIM LOCAL GRAU:

SONDA: ( ) SIM ( ) NÄO - TIPO:

PARECER DO PAD: 


\section{PREENCHER SOMENTE SE O PACIENTE É INDICADO PARA O POD \\ (PROGRAMA DE OXIGENOTERAPIA DOMICILAR)}

Gasometria Arterial em ar ambiente com 20 mim de repouso absoluto. 1

$\mathrm{PH}=$ $\mathrm{pO}_{2}=$ $\mathrm{mmHg}$

$\mathrm{pCO}_{2}=$ $\mathrm{mmHg}$ Sat. $\mathrm{O}_{2}=$ $\%$

Prescrição atual de oxigênio terapia litros de oxigênio por minuto durante horas/dia

Prescriçăo recomendada:

litros de oxigènio por minuto durante repouso litros de oxigènio por minuto durante atividade litros de oxigênio por minuto durante sono

\section{CRITÉRIOS DE INCLUSĀO}

Oxigenoterapia contínua com paciente em repouso: (sem falar por pelo menos 20 minutos)

$>\mathrm{PaO}_{2} \leq 55 \mathrm{mmHg}$ ou $\mathrm{Sa} \mathrm{O}_{2} \leq 88 \%$ ou

$>\mathrm{PaO}_{2} 56-59 \mathrm{mmHg}$ associado a:

> edema causado por ICC descompensada;

$>$ evidência de cor pulmonale;

$>$ hematócrito $\geq 56 \%$

$>$ Paciente deve ser aderente ao tratamento farmacológico adequado.

$>$ Ter deixado de fumar, caso fumante.

OBS:

- Solicitar PAD com antecedência de pelo menos 7 dias antes da alta.

- Não esquecer de avisar o PAD quando da alta. Ramal: 9481/9229/9213. 


\author{
ANEXO G \\ UNIVERSIDADE DE SÄO PAULO \\ HOSPITAL UNIVERSITÁRIO \\ PROGRAMA DE ATENDIMENTO DOMICILIARIO - PAD \\ TERMO DE ORIENTACAĀO AOS FAMILIARES
}

1 - Critérios para admissão e permanência do paciente no programa:

- Ser usuário matriculado no HU, pertencente à Comunidade USP ou Butantă.:

- Apresentar necessidade de atençăo multiprofissional;

- Ser elegivel conforme avaliação da equipe multiprofissional do PAD;

- Morar dentro da área de abrangência: Rio Pequeno, Raposo Tavares, Vila Sônia, Morumbi, Butantă:

- Ter cuidador familiar responsável, por 24 h, maior de 18 anos.

2 - Funcionamento do programa:

\title{
Equipe Multiprofissional
}

O atendimento é realizado por uma equipe multiprofissional. A familia e o paciente devem aceitar 0 atendimento de todos os membros da equipe.

\section{Transporte}

O programa năo dispōe de veiculo para remover o paciente em situação de emergência. consultas, exames, atendimento em reabilitaçăo, etc.

\section{Emergência}

A familia deverà providenciar o encaminhamento do paciente, em veiculo por ela providenciado, ao Pronto Socorro do HU ou ao mais próximo da residência.

"O PAD năo substitui o Hospital ou o Pronto Socorro".

\section{Visita}

Cabe à equipe do PAD definir a periodicidade das visitas considerando sempre a complexidade da doença, o nivel de cuidados e as caracteristicas da familia/cuidador. No dia da visita, deixar o paciente higienizado e aguardando a equipe, juntamente com o cuidador responsàvel.

\section{Cuidador}


A familia deverá organizar-se para a prestaçāo dos cuidados diretos e indiretos ao paciente. garantindo a viabilidade do atendimento domiciliário.

\section{Material/Medicamento}

O PAD-HU não fornece materiais (gazes, luvas, algodăo, fraldas descartáveis, etc), bem como medicamentos.

\section{Equipamentos Hospitalares}

A aquisição ou aluguel de equipamentos hospitalares (camas, cadeiras de rodas, cadeira higiênicas, etc.) é de responsabilidade da familia. No caso do eventual empréstimo realizado pelo PAD, compete à familia a conservação, uso adequado e devolução assim que solicitado.

\section{Atendimento por telefone}

O PAD funciona de $2^{\mathrm{a}}$ à $6^{\mathrm{a}}$ feira das 7 h00 às 16 h00.

A familia/cuidador ou paciente poderăo recorrer aos telefones abaixo para orientaçăo e informação:

3039.9481 - Secretária do PAD

3039.9332 ou 3039.9460 - Serviço Social

\section{Cancelamento do Atendimento}

O atendimento poderá ser cancelado caso ocorra:

- Falta de envolvimento ou colaboração do cuidador, do paciente e/ou da familia ao tratamento proposto por qualquer um dos membros da equipe;

- Mudanças no quadro clínico e/ou ou familiar que inviabilizem o tratamento;

- Descumprimento dos critérios iniciais de admissão e permanência;

- Alta, óbito ou Admissăo em outro serviço

\section{Fotografia}

O PAD poderá fotografar o paciente, familia e/ou residència para fins didáticos ou cientificos 


\section{Óbito}

Entrar em contato telefônico com o Serviço Social para orientaçăo.

"A Equipe multiprofissional do PAD entende que cuidar è um processo que deve envolver os profissionais, as familias, os cuidadores. a comunidade e sobretudo os pacientes. A medida

que esse relacionamento revestir-se cada vez mais de bons vinculos, alto grau de responsabilidade, respeito, carinho a atenção, maior sucesso terá o tratamento e maior qualidade de vida terá o usuário". Equipe do PAD - HU.

DATA:

Paciente:

Entrevistado:

Parentesco:

Ciente das regras de funcionamento do PAD- HU

Assistente Social: 
Paciente R.G.:

Idade: Sexo: Cor: Estado Civil:

Naturalidade:

Endereço: Telefone:

Data de Entrada: Data de Alta:

Encaminhamento:

\section{ANAMNESE}

Queixa principal:

História da Moléstia Atual:

Antecedentes pessoais:

Hábitos: Tabagismo( ) etilismo( ) drogas ( ) outros ( )

\section{História Médica}

1 - Auto hemostasia:

Teve hemorragia em cirurgia anterior?

Ao cortar-se perdura por muito tempo o sangramento?

S N Não sabe

Em contusōes tem hematomas facilmente?

S N Nāo sabe

S N Não sabe

2 - Distúrbios cardiovasculares:

Sofre de cardiopatia?

É portador de prótese cardíaca?

Cansa-se muito ao subir escadas?

Tem edema maleolar?

Tem dores precordiais?

Tem cefaléias frequentes?

$\begin{array}{lll}\text { S } & \text { N } & \text { Não sabe } \\ \text { S } & \text { N } & \text { Não sabe } \\ \text { S } & \text { N } & \text { Não sabe } \\ \text { S } & \text { N } & \text { Não sabe } \\ \text { S } & \text { N } & \text { Não sabe } \\ \text { S } & \text { N } & \text { Não sabe }\end{array}$

Em que regiāo se manifesta cefaléia?

Sua pressão arterial normalmente qual é?

PA no momento

Conclusões sobre o item:

3 - Distúrbios do metabolismo glicídico:

É portador de diabetes?

S N Nāo sabe

Tem controles periódicos?

Já fez exames de glicemia?

Sua micçāo é acentuada?

Toma muito líquido?

S N Não sabe

Conclusões sobre o item: 
4- Processos alérgicos:

\begin{tabular}{|c|c|c|c|}
\hline $\begin{array}{l}\text { É alérgico a aiguma substância? } \\
\text { Qual? }\end{array}$ & s & N & Nāo sabe \\
\hline Já tomou penicilina? & $s$ & $\mathrm{~N}$ & Não sabe \\
\hline Já foi anestesiado anteriormente? & $S$ & $\mathrm{~N}$ & Nāo sabe \\
\hline
\end{tabular}

\section{5 - Distúrbios motores:}

$\begin{array}{llll}\text { Já teve alguma convulsāo? } & \text { S } & \text { N } & \text { Não sabe } \\ \text { Tem algum parente epiléptico? } & S & N & \text { Não sabe }\end{array}$

Conclusões sobre o item:

6-Quando foi ao médico pela última vez?

Porquê?

7 - Quais doenças teve na infância? Caxumba ( ) $\quad$ Catapora ( )
Outras ( )

8 - Tem ou teve alguma doença?

$\begin{array}{llll}\text { Úlcera } & (\text { ) } & \text { Hepatite } & (\text { ) } \\ \text { Anemia } & (j) & \text { Asma brônquica } & (\text { ) } \\ \text { Doenças venéreas } & (j & \text { HIV+ } & (\text { ) } \\ \text { Outras }(\text { ) } & & \text { Com quem faz tratamento? } \\ \text { Há quanto tempo? } & \end{array}$

9 - Está tomando algum medicamento? $\quad \mathrm{S} \quad \mathrm{N} \quad$ Qual?

10 - Já foi hospitalizado?

Porquê?

Já foi submetido a alguma cirurgia?

Qual?

Já recebeu transfusão sanguínea?

Porquê?

1 - Está grávida?. S N Não sabe Quantos meses?

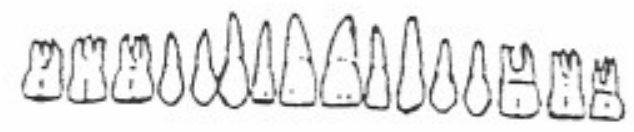

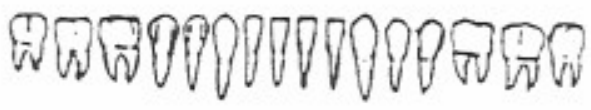

Assinatura do Paciente / Responsável

EX-EXTRA BUCAL

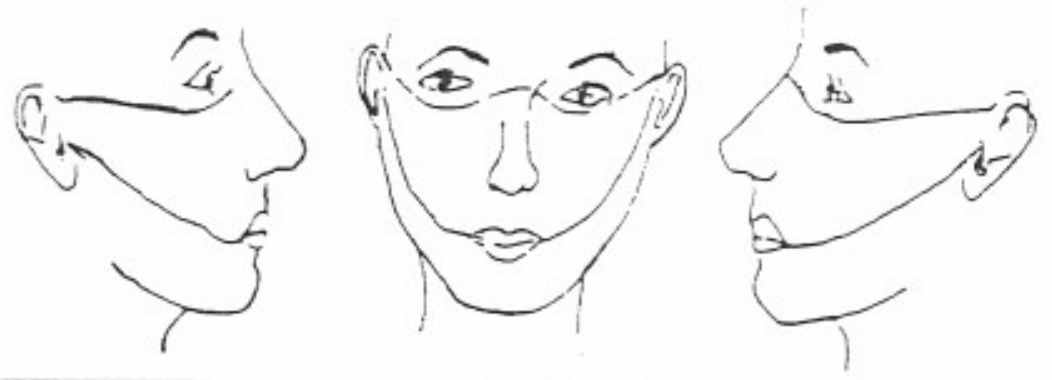

